\title{
Europe: A Survey of Gender Budgeting Efforts
}




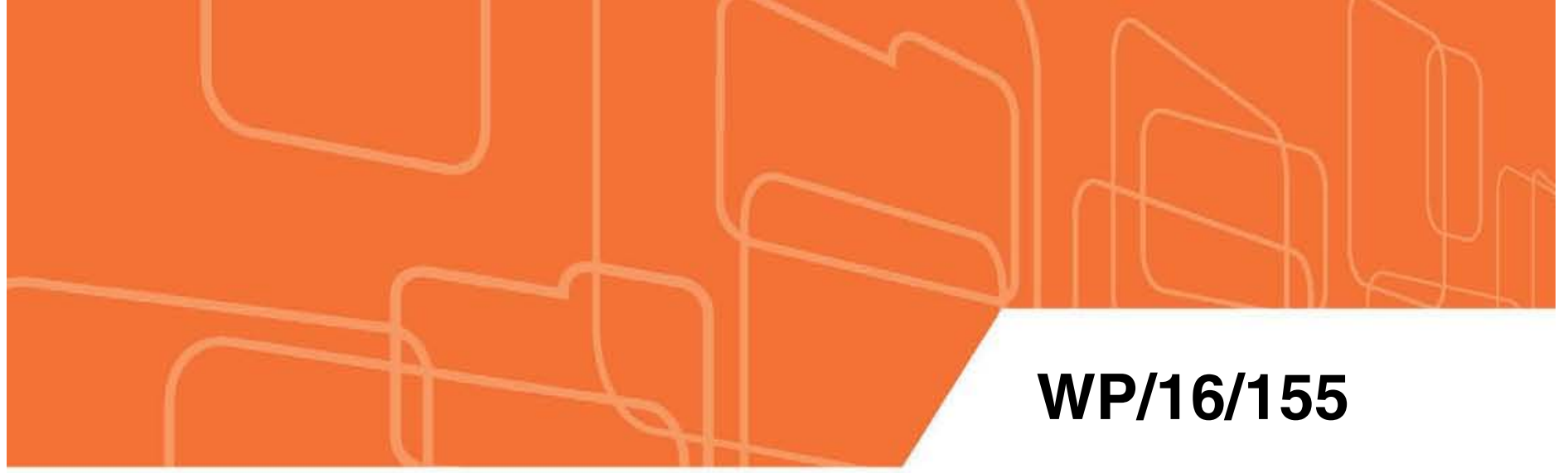

\section{IMF Working Paper}

Europe: A Survey of Gender Budgeting Efforts

by Sheila Quinn

I N T ER N A T I O N A L M O N E T A R Y FU N D 


\title{
IMF Working Paper
}

Research Department and Strategy, Policy, and Review Department

\section{Europe: A Survey of Gender Budgeting Efforts}

\section{Prepared by Sheila Quinn*}

Authorized for distribution by Prakash Loungani and Catherine Pattillo

July 2016

\section{IMF Working Papers describe research in progress by the author(s) and are published to elicit comments and to encourage debate. The views expressed in IMF Working Papers are those of the author(s) and do not necessarily represent the views of the IMF, its Executive Board, or IMF management.}

\begin{abstract}
This paper surveys European gender budgeting efforts, which have enjoyed sustained support for more than a decade and a half. In a number of countries, gender budgeting led to significant changes in budget legislation and administrative practices. In some countries, it is also possible to tie gender budgeting efforts to expenditure and revenue policy reforms. At a time of continued fiscal austerity in Europe, gender budgeting can help inform fiscal policies to ensure gender-related goals are met. Civil society has played an active role in advocating for effective gender budgeting.
\end{abstract}

JEL Classification Numbers: H00, I3, J16

Keywords: Gender budgeting, Europe, fiscal policies and administration, gender inequality

Author’s E-Mail Address: sheilagquinn@gmail.com

*Independent scholar. I would like to thank Janet Stotsky and Lisa Kolovich for support and guidance, Suhaib Kebhaj for effective research assistance, Jing Wang and Biva Joshi for remarkable logistical and administrative support, and Diane Elson for useful suggestions. I would also like to thank the many officials and friends within the administrations and civil society organizations throughout Europe engaged with gender budgeting who provided much valuable information and insight. This paper is part of a research project on macroeconomic policy in low-income countries and is supported by the United Kingdom's Department for International Development (DFID). It does not necessarily represent the views of the International Monetary Fund or of DFID. 


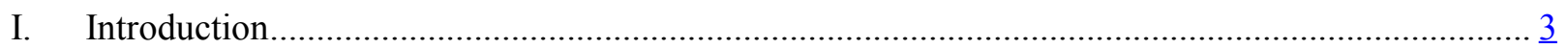

II. Case Studies of Gender Budgeting Initiatives in Western Europe/European Union ....................... $\underline{8}$

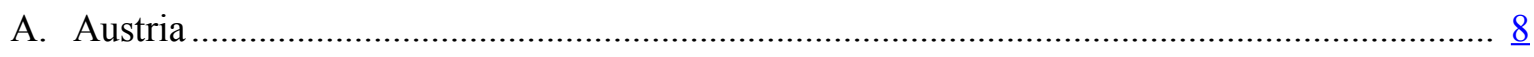

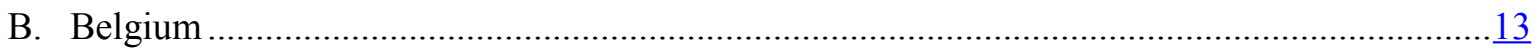

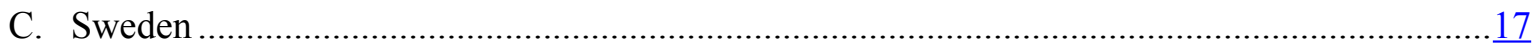

D. Finland

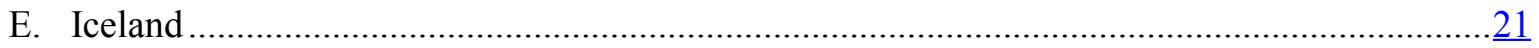

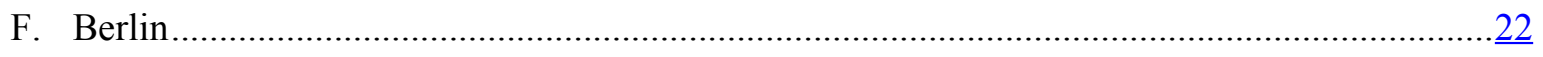

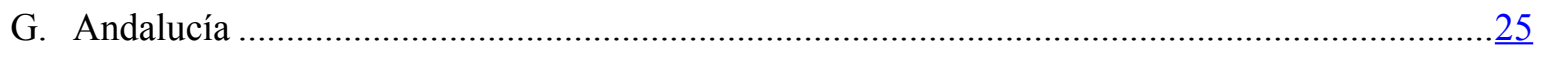

III. Case Studies of Gender Budgeting Initiatives in Emerging Markets .........................................29

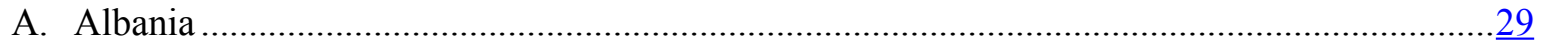

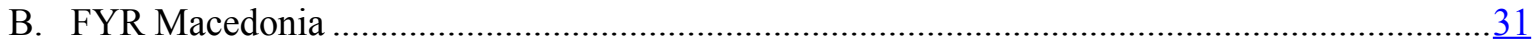

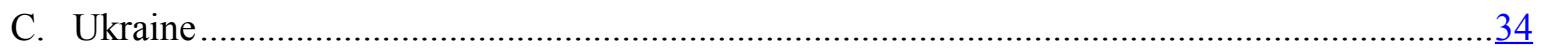

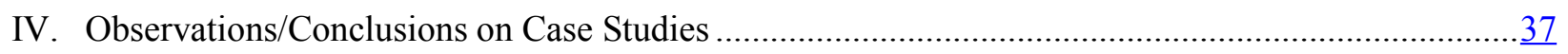

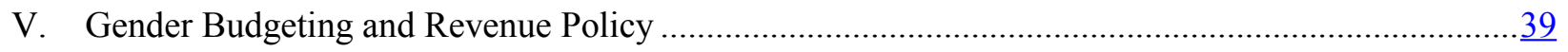

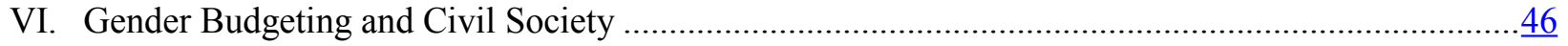

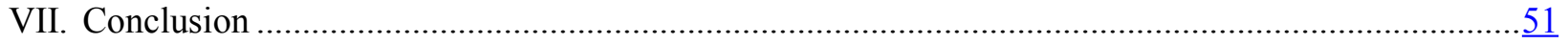

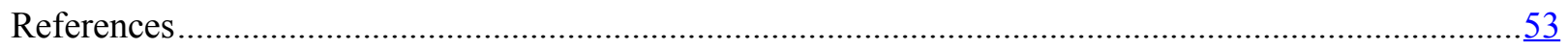

Tables

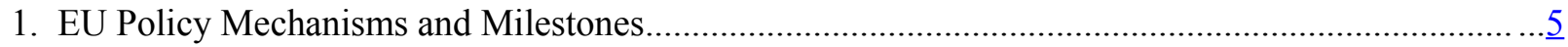

2. European Gender and Income Equality Indicators ............................................................ 9

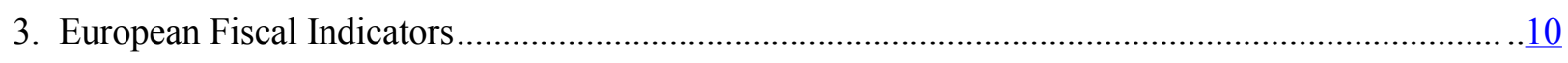

4. Albania: Gender Budgeting Programs, Budget 2015 .......................................................... $\underline{30}$

Figure

1. European Countries by Level of Economic Development ........................................................... Appendix

A. Gender Budgeting in Europe Data Template ......................................................................... 


\section{Introduction}

Gender budgeting in Europe provides many examples of where gender-related goals have been integrated into fiscal institutions and policies. Adopted in jurisdictions across the globe, gender budgeting is an initiative to use fiscal policy and administration to advance gender equality and women's development. In Europe, this initiative has focused almost exclusively on addressing gender-related goals through the expenditure side of the budget. Some European countries have, however, incorporated gender-related goals into revenue and welfare policies, important areas for women's economic empowerment. The combined effect of structural reforms and retrenchments to social protections system, as well as recent trends in unemployment in Europe, suggest that women are at a heightened risk of poverty in a number of European countries. There is, therefore, a greater need for the region to take gender-related goals into account in budgeting in the face of continued austerity. ${ }^{1}$

Europe has made progress in gender equality in recent decades. In the early 2000 s, there was an expectation that gender budgeting would "liberate" and "elevate" gender mainstreaming to the level of macroeconomic policy and thus expedite the realization of oft-projected gender equality goals (Holvoet, 2006). Gender mainstreaming - the strategy which calls for the consideration of a gender perspective in the development and implementation of all government policies - had largely failed to penetrate into the domain of fiscal policy. Gender budgeting challenges the traditionally held view of the budget as a gender-neutral instrument, and this paper demonstrates that in many countries the reluctance - and even resistance - of Ministries of Finance to embrace the idea has given way to a broad and diverse tapestry of initiatives. This paper provides a survey of gender budgeting initiatives in Europe. ${ }^{2}$

Looking across Europe, in some instances, national and regional governments have legislated for gender budgeting (e.g., Austria, Belgium, and Andalucía); others have initiated changes to the institutions of the budget (e.g., Albania, Belgium, and Iceland); while others have recommitted to the fundamental concept of marrying equality policy with economic policy (e.g., Sweden, Finland, and Iceland). Alongside this, civil society organizations have brought the focus squarely on revenue policy, particularly taxation, and on welfare benefits, dimensions of the budget largely outside the reach of government-led gender budgeting initiatives.

So how fares gender budgeting in Europe, what is its contribution to the broader agenda of gender equality and women's empowerment, and how might European countries leverage the change in institutions, law, and practice to move things forward? The study aims to answer

\footnotetext{
${ }^{1}$ A subsequent study will examine the implications of austerity in the European Union on gender-related goals.

${ }^{2}$ This paper is part of a larger research project on gender budgeting, which surveys and assesses experiences cross the world. See Stotsky (2016) for an overview of results of the project.
} 
these questions in the context of the gender equality policy environment within which gender budgeting is operating.

The discussion begins with an overview of how the European Union (EU) has influenced the evolution of gender equality policy, not only within its Member States, but also across the broader European continent with which the EU has some form of formal relationship. This is followed with case studies on what we determined where the most significant European gender budgeting initiatives, with examples from Western Europe and emerging markets in the region. It is beyond the scope of this paper to evaluate the impact of gender budgeting on gender equality outcomes. The survey does illustrate, however, the level of commitment of many countries to gender budgeting and is timely in pointing to the need for evaluations of these important initiatives. While some have not been in place long enough to evaluate the impact on gender equality, others have, and in all cases there is benefit to be gained from an evaluation of the approach. We move on then to an overview of how revenue policy has been treated within the frame of gender budgeting. Following this, we take a look at how recent financial crises and recession and subsequent government austerity measures, have impacted on gender equality. We then turn to a discussion of the role of civil society in gender budgeting. Finally, we conclude with some observations that will inform further research and the application of gender budgeting.

\section{The EU's Gender Equality policy}

The history of gender equality policy in the European Union dates to the first EU gender directive in 1975 on the gender pay gap (Table 1). Following the 1995 UN World Conference on Women in Beijing, the EU endorsed gender mainstreaming as a guiding strategy toward gender equality and set about promoting the consideration of gender equality in all policy domains. In 1999, the Treaty of Amsterdam included the promotion of equality and the elimination of discrimination between men and women among the EU's fundamental tasks. Over the years, a number of sex equality-related directives were issued, and in 2006, these were brought together in the so-called Recast Gender Directive. Here, in one text, the objective was to clarify the main provisions regarding access to employment, including promotion; vocational training; working conditions, including pay; and social security schemes (NLEGE, 2014).

On aggregate, the EU has had a positive influence on the development of gender equality policy, not only on its Member States but also on other European countries, ${ }^{3}$ where candidacy for accession or other aid-related relationships require countries to work toward compliance with EU norms. It has been argued that some European countries, including some Member

\footnotetext{
${ }^{3}$ Twenty-eight of the 47 countries in Europe are members of the EU. Of the remaining nineteen, six are candidates and most, if not all, others have some formal agreement with the EU.
} 


\section{Table 1. EU Policy Mechanisms and Milestones}

\begin{tabular}{|c|c|}
\hline Policy mechanisms & Policy milestones \\
\hline EU Treaty & Equal pay included in original Treaty of Rome.The \\
\hline $\begin{array}{l}\text { Treaty of Rome } 1957 \text { but revised (and renamed) } \\
\text { when member states agree to changes to rules } \\
\text { and scope of EU actions. }\end{array}$ & $\begin{array}{l}\text { Treaty of Amsterdam (1997) stipulated the } \\
\text { promotion of equality between women and men } \\
\text { as one of the EU's fundamental tasks. }\end{array}$ \\
\hline Hard law & Equal pay and sex discrimination directives passed \\
\hline $\begin{array}{l}\text { EU directives (laws passed by the EU that must } \\
\text { be implemented in national law). }\end{array}$ & $\begin{array}{l}\text { in mid-1970s. ECJ interpreted this to include } \\
\text { indirect sex discrimination. }\end{array}$ \\
\hline $\begin{array}{l}\text { Interpretations of directives by European Court } \\
\text { of Jusitice (ECJ), which may override national } \\
\text { interpretations. }\end{array}$ & $\begin{array}{l}\text { Other directives on maternity leave, parental leave, } \\
\text { equal treatment for part-time workers passed in } \\
1990 \mathrm{~s} \text {. }\end{array}$ \\
\hline & $\begin{array}{l}\text { Consumer rights directives passed in } 2004 \text {, } \\
\text { amended } 2012 \text {. }\end{array}$ \\
\hline Soft law & Gender equality was central to EES up to 2005 (one \\
\hline $\begin{array}{l}\text { European Employment Strategy (EES): Soft law that } \\
\text { includes targets, plans, and recommendations, } \\
\text { but is voluntarist. }\end{array}$ & $\begin{array}{l}\text { of four pillars 1997-2003; and } 1 \text { of } 10 \text { guidelines, } \\
\text { 2003-2005). }\end{array}$ \\
\hline \multirow[t]{2}{*}{ Gender mainstreaming: Voluntarist. } & $\begin{array}{l}\text { In } 2000,60 \% \text { target for women's employment } \\
\text { rate in } 2010 .\end{array}$ \\
\hline & In 2002, targets set for childcare coverage by 2010 . \\
\hline Financial flows & Gender equality and gender mainstreaming \\
\hline $\begin{array}{l}\text { European structural funds: Support for less- } \\
\text { developed regions. }\end{array}$ & $\begin{array}{l}\text { included in criteria for European social funds } \\
\text { beginning in 1990s. }\end{array}$ \\
\hline
\end{tabular}

Rubery, 2015, p. 722 - reprinted with permission from the author.

States, would be worse off in terms of accommodating gender equality were it not for the influence of the EU (Rubery, 2015). While some countries have retreated from full compliance in the post-accession period (see, for example, Bretherton, 2001; Sedelmeier, 2009), the legislative harmonization brought about by the implementation of the Employment and Social Affairs Chapter of the acquis communautaire has legitimized women's claim to genuine equality (Sloat, 2004). Nevertheless, our discussion will touch on how the EU's focus on the social agenda as a whole, and particularly in relation to gender equality, has weakened considerably.

In line with, and to some extent because of, a Europe-wide policy push toward equal opportunities, and the ensuing increased participation of women in the labor market, there has been a change in the nature of gender relations across Europe. In addition to narrowing the gender employment gap, women are now entering higher education in most EU member states at a rate above men, and the traditional nuclear family has, in some measure, given way to a diversity of partnership and family models. Nevertheless, Rubery (2015) argues that this "unstoppable revolution" in gender relations has failed to result in a major change in the 
domestic division of labor. On this basis, she concludes that progress toward gender equality remains highly dependent on public policy.

There has been concern about the weakening of the EU's social agenda, including its gender equality policy for some time, and certainly prior to the recent financial and public debt crises (Crouch, 2015). The downgrading of gender equality policy by the EU institutions is clearly detrimental to the overall project of gender equality. With a shift in focus to "objectives around children, family functioning and family life" recent and ongoing social policy reform "looks over (or overlooks) gender equality" (Daly, 2011, p. 2).

\section{The European Employment Strategy}

The trajectory of the European Employment Strategy (EES), launched in 1997, is a good illustration of gender equality's downgrading. Of EU soft law instruments pertaining to gender equality, the EES is perhaps the principal one, given its economic focus. At the outset, equal opportunity between women and men was included as one of the Strategy's four pillars, and in 1998 a specific instruction to mainstream gender equality was included in the Strategy's guidelines. Linked to this strong emphasis on gender equality in economic policy was a decision by the EU Council of Ministers in 2000 to target women's employment at 60 percent and men's at 70 percent (Rubery, 2015). Throughout this period, the EU had a clear focus on increasing employment rates, and women were seen as central to achieving that objective (Barry, 2014). In 2003, however, the framework was abandoned and gender equality was relegated to one of ten guidelines. Further changes in 2005 saw gender equality reduced to a principle articulated in the preamble to the new Broad Economic Policy Guidelines, of which eight related to employment. The most recent changes in 2010, developed after the economic crisis, leave the principle of gender equality sidelined to the preamble and focus squarely on men's employment, seemingly overlooking the women's employment gains during the Lisbon process (Villa and Smith, cited in Barry, 2014).

Rubery's (2015) treatment of the literature dealing with the erosion of EU policy on gender equality prior to the crisis of 2008 points to a number of fronts on which this was evident. These include the co-option and transformation of gender equality ideals to satisfy other policy objectives (Stratigaki, cited in Rubery, 2015), such as relieving demographic pressures, promoting flexibility in the work force to comply with market demands, and the "Make Work Pay" policy, designed to mitigate welfare dependency (Rubery, 2015, p. 726). While women's integration into the labor market has expanded, this has not resulted in increased economic independence or a lessening in the dual burden of paid work and unpaid work in the household (Pearson, 2014; Pearson and Elson, 2015). In addition, while women increased their share of the labor market, they are over-represented in nonstandard jobs, with the added associated precarity. There has been a shift from gender equality to family policy in some former Soviet Union countries (Sedelmeier, 2009); and a traditionally conservative political perspective on gender norms and roles continues to influence policy making, even in some of 
the founding members of the European Union. For some, notably Germany, the impact of recent family policies has served mostly as "emancipation for the privileged" while leaving low-income women worse off (Henninger et al., 2008), and, on aggregate, reinforces, rather than reduces, dependence on male breadwinners (Palier and Thelen, 2010).

Since the 2008 crisis, there is growing evidence that gender equality policies have all but been abandoned, while both EU and national level policies have favored neoliberal marketexpanding approaches that are, on the face of it gender neutral and, some would argue, effectively regressive in relation to gender equality (Daly, 2011, Barry and Conroy, 2014; Pearson and Elson, 2015; Rubery, 2015).

European countries viewed by level of economic development and gender inequality

Most European countries are considered advanced economies (Figure 1). However, there are also a number of emerging markets and, in 2014, Moldova was considered low income.

\section{Figure 1. European Countries by Level of Economic Development}

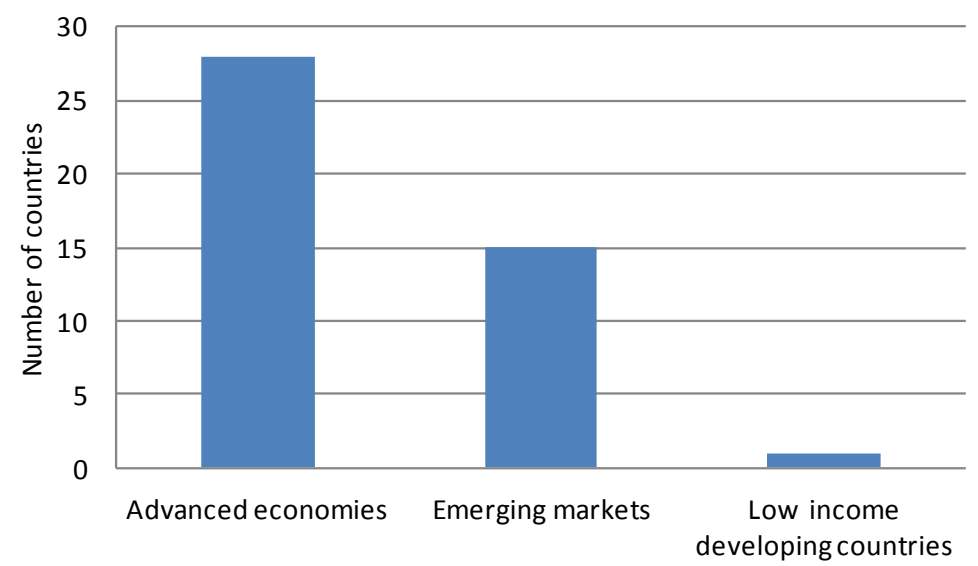

Sources: IMF classification in the World Economic Outlook (WEO).

Note: Advanced economies include: Austria, Belgium, Cyprus, Czech Republic, Denmark, Estonia, Finland, France, Germany, Greece, Iceland, Ireland, Israel, Italy, Latvia, Lithuania, Luxembourg, Malta, Netherlands, Norway, Portugal, San Marino, Slovak Republic, Slovenia, Spain, Sweden, Switzerland, and the United Kingdom. Emerging markets include: Albania, Belarus, Bosnia and Herzegovina, Bulgaria, Croatia, Hungary, Kosovo, Macedonia FYR, Montenegro, Poland, Romania, the Russian Federation, Serbia, Turkey, and Ukraine. Moldova is low income.

European countries generally enjoy a high level of gender equality, compared to other countries in the world. Table 2 presents information on individual indicators of equality. Labor force participation of women is on average about two-thirds that of men, while unemployment rates are about even. There remains a wage gap, with women earning on an hourly basis on average about 80 percent of men. 
Table 3 provides the fiscal aggregates in Europe. It shows that the public sector in Europe tends to be large relative to the economy (measured either by revenues or expenditures as a share of GDP). Some of the advanced economies have a public sector that exceeds one-half of national income, while almost all countries have a public sector that comprises more than 30 percent of national income. Some countries are heavily indebted, with debt to GDP ratios over 100 percent.

\section{Case Studies of Gender Budgeting Initiatives in Western Europe/European Union}

\section{A. Austria}

\section{Summary}

Gender budgeting in Austria has gained worldwide attention, in part because of the initiative's constitutional and legislative underpinnings, and its promotion by the Director General, Budget and Public Finance in the Ministry of Finance at the time of its introduction. Gender budgeting was noteworthy for being incorporated into a major budget reform process at the federal level, and therefore, for the integration of gender as a category of analysis and control in all of the institutions of the budget, extending all the way to the Court of Audit. As part of the reform, gender equality became integral to a new constitutionally mandated budgetary principle, that of performance-orientated budgeting. In addition, reform of the regulatory impact assessment process introduced the concept of "effective" equality between men and women, and required that all new laws, regulations and directives, as well as other large government projects be assessed for their gender impact (Schratzenstaller, 2014). These characteristics render Austria's gender budgeting initiative one of the most institutionally robust in Europe, and arguably provides a strong legislative basis for a refinement of its methods so as to effect more substantive gender equality outcomes in line with socioeconomic priorities. The main methodological tool for gender budgeting in Austria is the identification of a gender equality objective for each budget chapter as an integral element of performance-oriented budgeting. A weakness of Austria's approach is a built-in disincentive to the identification of relevant and potentially transformative gender equality objectives. A 2015 evaluation shows that budget personnel, while expressing commitment to the goal of gender equality, largely lacked capacity for meaningful gender analysis. 
Table 2. European Gender and Income Equality Indicators

\begin{tabular}{|c|c|c|c|c|c|c|c|c|}
\hline \multirow[b]{2}{*}{ Country } & \multirow[t]{2}{*}{$\begin{array}{c}\text { GDI, time- } \\
\text { cons is te nt }^{1} \\
(2013)\end{array}$} & \multirow[t]{2}{*}{$\begin{array}{c}\text { Gini } \\
\text { coefficie nt }^{2} \\
(\text { scale } 0-100)\end{array}$} & \multirow{2}{*}{$\begin{array}{c}\text { Gross } \\
\text { secondary } \\
\text { enrollment } \\
\begin{array}{c}\text { female to male } \\
\text { ratio }\end{array}\end{array}$} & \multicolumn{2}{|c|}{$\begin{array}{c}\text { Labor force } \\
\text { participation rate } \\
\text { (ages 15-64) }\end{array}$} & \multicolumn{2}{|c|}{ Une mployment } & \multirow{2}{*}{$\begin{array}{c}\text { Me an monthly } \\
\text { e arnings of } \\
\text { e mployees } \\
\text { female to } \\
\text { male ratio }\end{array}$} \\
\hline & & & & $\begin{array}{l}\text { female to } \\
\text { male ratio }\end{array}$ & $\begin{array}{c}\text { Female } \\
\text { (percent) }\end{array}$ & $\begin{array}{l}\text { female to } \\
\text { male ratio }\end{array}$ & $\begin{array}{c}\text { Female } \\
\text { (percent) }\end{array}$ & \\
\hline Albania & 0.951 & 29.0 & 0.95 & 0.70 & 51.7 & 0.78 & 13.8 & n.a. ${ }^{3}$ \\
\hline Austria & 0.943 & 30.5 & 0.96 & 0.87 & 70.6 & 1.00 & 4.9 & 0.62 \\
\hline Belarus & 1.012 & 26.0 & 0.96 & 0.89 & 62.2 & 0.59 & 4.3 & 0.77 \\
\hline Belgium & 0.992 & 27.6 & 0.97 & 0.86 & 62.1 & 0.94 & 8.1 & 0.78 \\
\hline Bosnia and Herzegovis & n.a. & 33.0 & n.a. & 0.63 & 42.0 & 1.15 & 30.9 & n.a. \\
\hline Bulgaria & 0.990 & 36.0 & 0.96 & 0.89 & 63.7 & 0.86 & 11.9 & 0.81 \\
\hline Croatia & 0.982 & 32.0 & 1.04 & 0.84 & 58.4 & 0.91 & 16.8 & 0.90 \\
\hline Cyprus & 0.967 & 34.3 & 1.02 & 0.83 & 66.0 & 0.90 & 14.9 & 0.78 \\
\hline Czech Rep. & 0.984 & 26.1 & 1.00 & 0.81 & 64.9 & 1.39 & 8.2 & 0.79 \\
\hline Denmark & 0.983 & 29.1 & 1.01 & 0.94 & 75.5 & 1.09 & 7.3 & 0.85 \\
\hline Estonia & 1.032 & 33.2 & 0.99 & 0.91 & 71.9 & 0.89 & 8.3 & 0.74 \\
\hline Finland & 1.003 & 27.1 & 1.05 & 0.95 & 73.4 & 0.85 & 7.5 & 0.81 \\
\hline France & 0.991 & 33.1 & 1.01 & 0.88 & 66.6 & 1.00 & 10.4 & 0.82 \\
\hline Germany & 0.963 & 30.1 & 0.95 & 0.87 & 72.0 & 0.88 & 4.9 & 0.82 \\
\hline Greece & 0.960 & 36.7 & 0.97 & 0.76 & 58.6 & 1.29 & 31.3 & n.a. \\
\hline Hungary & 0.985 & 30.6 & 0.98 & 0.83 & 58.4 & 1.01 & 10.2 & n.a. \\
\hline Iceland & 0.999 & 26.9 & 1.01 & 0.95 & 82.3 & 0.88 & 5.2 & 0.82 \\
\hline Ireland & 0.973 & 32.5 & 1.02 & 0.81 & 62.6 & 0.72 & 10.8 & 0.73 \\
\hline Israel & 0.969 & 42.8 & 1.02 & 0.88 & 67.0 & 1.02 & 6.3 & 0.66 \\
\hline Italy & 0.966 & 35.2 & 0.99 & 0.72 & 53.7 & 1.13 & 13.1 & n.a. \\
\hline Kosovo & n.a. & 26.7 & n.a. & n.a. & n.a. & n.a. & n.a. & n.a. \\
\hline Latvia & 1.019 & 35.5 & 0.97 & 0.93 & 72.5 & 0.89 & 10.5 & 0.83 \\
\hline Lithuania & 1.028 & 35.2 & 0.96 & 0.94 & 71.4 & 0.80 & 10.5 & 0.86 \\
\hline Luxembourg & 0.960 & 34.8 & 1.03 & 0.83 & 62.2 & 1.25 & 6.6 & 0.87 \\
\hline Macedonia, FYR & 0.945 & 44.1 & 0.99 & 0.66 & 51.1 & 1.00 & 28.9 & n.a. \\
\hline Malta & 0.949 & n.a. & 1.04 & 0.61 & 47.6 & 1.00 & 6.5 & 0.87 \\
\hline Moldova & 0.993 & 28.5 & 1.02 & 0.90 & 43.7 & 0.63 & 3.9 & n.a. \\
\hline Montenegro & n.a. & 33.2 & 1.01 & 0.79 & 52.1 & 1.09 & 20.8 & n.a. \\
\hline Netherlands & 0.947 & 28.0 & 0.98 & 0.88 & 74.3 & 0.87 & 6.2 & 0.57 \\
\hline Norway & 0.995 & 25.9 & 0.98 & 0.95 & 75.8 & 0.89 & 3.3 & 0.85 \\
\hline Poland & 1.009 & 32.4 & 0.99 & 0.82 & 60.3 & 1.14 & 11.1 & 0.85 \\
\hline Portugal & 0.983 & 36.0 & 1.00 & 0.91 & 70.1 & 1.01 & 16.6 & 0.79 \\
\hline Romania & 0.988 & 27.3 & 0.98 & 0.78 & 56.9 & 0.84 & 6.6 & 0.89 \\
\hline Russian Federation & 1.013 & 41.6 & 0.98 & 0.87 & 68.6 & 0.88 & 5.2 & n.a. \\
\hline Serbia & 0.956 & 29.7 & 1.02 & 0.77 & 53.5 & 1.35 & 26.0 & n.a. \\
\hline Slovak Rep. & 0.992 & 26.1 & 1.01 & 0.80 & 62.2 & 1.04 & 14.5 & 0.76 \\
\hline Slovenia & 1.004 & 25.6 & 0.99 & 0.91 & 67.3 & 1.19 & 11.2 & 0.97 \\
\hline Spain & 0.979 & 35.9 & 1.01 & 0.85 & 68.3 & 1.05 & 27.3 & 0.77 \\
\hline Sweden & 1.008 & 27.3 & 0.98 & 0.94 & 78.6 & 0.96 & 7.9 & 0.86 \\
\hline Switzerland & 0.961 & 31.6 & 0.97 & 0.88 & 78.0 & 1.05 & 4.5 & 0.77 \\
\hline Turkey & 0.899 & 40.2 & 0.95 & 0.43 & 32.2 & 1.31 & 11.9 & 1.01 \\
\hline Ukraine & 0.998 & 24.6 & 0.98 & 0.85 & 62.6 & 0.74 & 6.7 & 0.75 \\
\hline United Kingdom & 0.965 & 32.6 & 1.00 & 0.86 & 70.3 & 0.89 & 7.0 & 0.64 \\
\hline Regional average & 0.980 & 31.8 & 0.99 & 0.83 & 63.4 & 0.98 & 11.5 & 0.80 \\
\hline
\end{tabular}

Sources: World Bank, World Development Indicators database; Stotsky et al. (2016); and IMF staff estimates.

Note: Values are for 2013 or latest year available.

$1 /$ The GDI is an index of gender equality, which generally ranges from $0-1$, with higher numbers signifying more equality; please see Stotsky et al. (2016) for further details.

2/A higher Gini coefficient implies more inequality.

3/ Data are not available. 
Table 3: European Fiscal Indicators

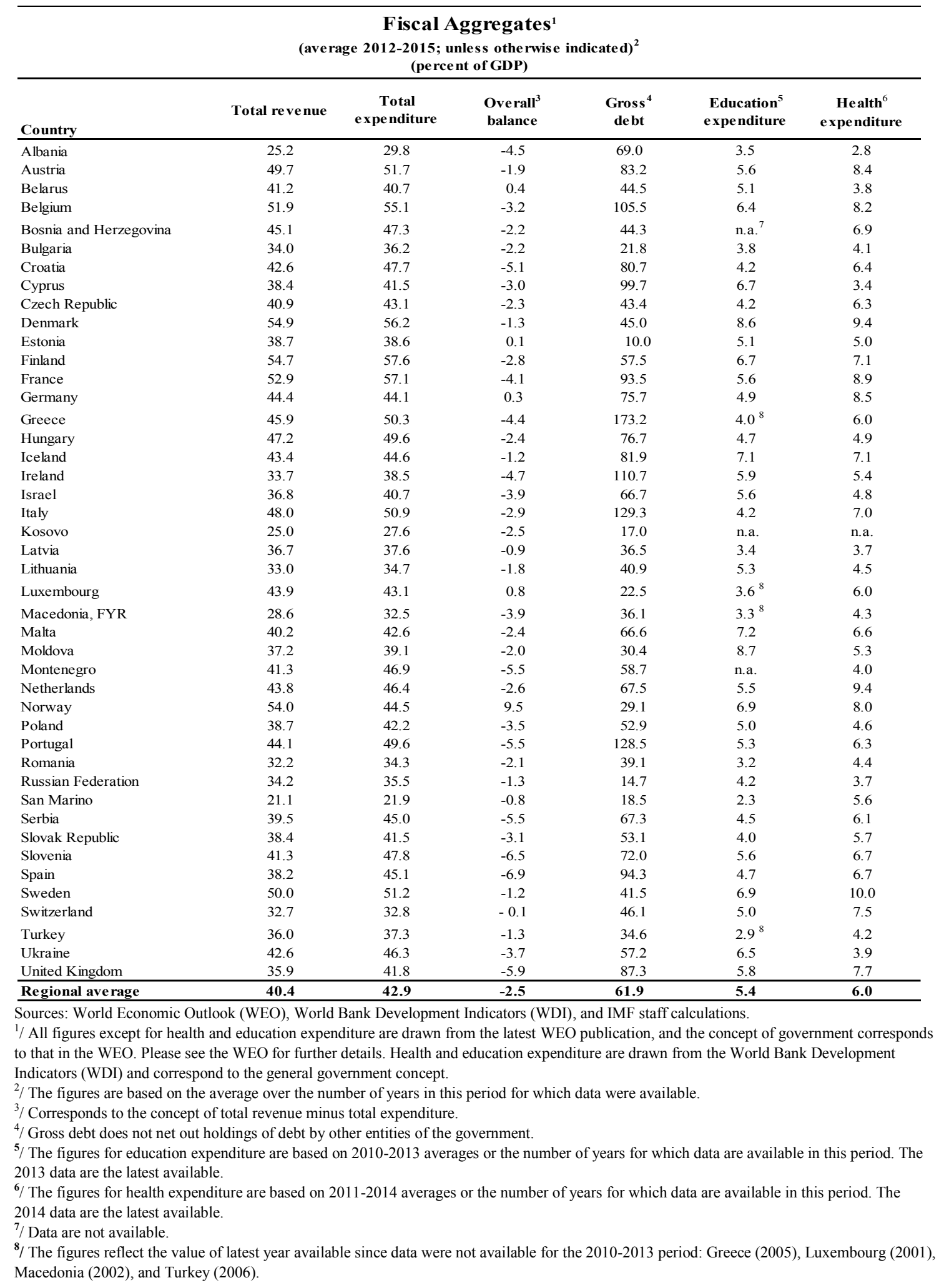




\section{Case study}

Gender budgeting was first put on a formal standing in Austria following a Ministerial Council decision in March 2004. At this time, the Ministry of Finance issued guidelines announcing the goal of applying gender mainstreaming to all budgetary measures and requesting all government departments to nominate pilot projects. The resultant analysis was included in the budget documentation and in the legislative texts relating to the Federal Finance Acts for the budgets 2005/2006 and 2007/2008 (Frey and Kohnen, 2012). In 2006 the Federal Ministry of Finance introduced a regulation to give a legal basis to this new instrument, then referred to as "gender audits" (Fritz, 2011). This early approach was project oriented, designed to single out individual budget lines or tasks.

While gender mainstreaming provided the initial framework for gender budgeting, Austria's federal budget reform process incorporated gender budgeting as a distinct and integral dimension. New legislation and a constitutional amendment in 2007 set out the scope and timeframe for budget reform. Changes to the constitution included a mandate to target defacto equality between women and men in the management of the budget. The provision applied to all levels of government:

"Federation, Laender and municipalities are to strive for the effective equality of men and women in their budget management" (Article 13, para. 3).

At the federal level, this provision is reinforced by the principle of "outcome orientation," articulated in Article 51, paragraph 8:

"In the budget management of the Federation the fundamental principles of impact orientation, especially considering the objective of the effective equality of men and women, transparency, efficiency and the most faithfully possible representation of the financial situation of the Federation, are to be observed" (Fritz, 2011).

By 2009, a binding Medium Term Expenditure Framework and strategy report would discipline the budgetary process, with carry-forward flexibility for line ministries an additional innovation of phase one of the budget reform. During the second phase, officials moved to performance, or outcome oriented budgeting, and accrual budgeting and accounting by 2013. This would in effect transform the budget from the traditional cameralistic system to one where the budget is used as a strategic policy instrument, with the focus on the presentation of results, and where performance accountability is paramount.

The Austrian federal administration views the constitutionally defined objective of gender equality as corresponding to the internationally established concept of gender budgeting (Steger, 2010). Gender budgeting thus constitutes the financial policy instrument for the implementation of Austria's gender mainstreaming strategy at the federal level (Ibid.). 
The budget reform process also involved changes to the Federal Budget Act (organic budget law) and here also "effective equality" is cited as "a target acquisition of budget management." The Federal Budget Act characterizes gender budgeting as involving the analysis of the impacts of administrative actions and budget policy and the application of corrective measures, if necessary, to the achievement of equality. In addition, gender budgeting is further supported by a 2013 reform of the regulatory impact assessment framework. Gender equality, which was already part of the regulatory framework, was reformulated to ensure that the 'effective' (or de-facto) equality between men and women is to be assessed. This regulatory process applies to all new laws, regulations, directives, as well as large government projects. Of particular relevance to gender equality is the assessment of impact on participation in the labor market on women and men, and the impact on income (Schratzenstaller, 2014).

Under the new structure, the annual budget is organized on three levels: chapter, global, and detail budgets. Each chapter has a maximum of five outcome objectives, one of which is to address gender equality. Objectives may be oriented externally in line with the line ministries obligations to gender equality, or internally relating to the ministry's human resource policy.

Conscious of the change in work culture that the reform process would entail, the Ministry of Finance kept external consultancies to a minimum so as to allow staff to adapt and implement the system, and in this way build capacity for new processes. In line with this model, but at odds with a gender mainstreaming approach, there was no accommodation for consultation with civil society, and therefore for the inclusion of women's voice. While budget officials can employ their expertise toward new budget processes, their expertise in addressing gender equality was at a low baseline. There is no evidence that budget officials were supplied with sufficient expertise - either through sustained capacity building or ongoing gender experts - to adequately undertake their newly mandated gender equality budgetary obligations.

Since the current gender budgeting initiative only came into effect in 2013 (notwithstanding the preparation period from 2009), it is still early days for evaluation. In order to report on progress to date, we rely on two studies: one supported by the European Union Programme for Employment and Social Solidarity (Schratzenstaller, 2014); and the other an evaluation of the budget reform commissioned by the Austrian administration (Hammerschmid and Grunwald, 2014).

The draft budget for 2013 included 123 outcome objectives, of which 28 were gender equality objectives, each with an average of two to three indicators. The defined gender equality objectives and measures addressed important policy areas, including the gender pay gap, reconciliation of work and family life, education and professional careers and representation of women in the boardroom (Schratzenstaller, 2014). Also included were measures to improve the gender database in a number of key ministries as well as in the 
Court of Audit. Parliamentary debate on the draft budget focused on the broad swathe of performance related information, and in particular to the gender related information. Likewise, the Parliamentary budget committee paid significant attention to outcome objectives and their ambitiousness, indicators and measures (Ibid.).

A recent evaluation of the budget reform process touched briefly on the gender budgeting dimension (Hammerschmid and Grunwald, 2014). The evaluation was based on interviews with budget officials. While the majority of respondents were positive about the integration of gender equality, many questioned its prominence as one of a maximum of five outcome objectives. Respondents felt that, at this early stage in the reform process, it was unrealistic to give the same weight to gender equality as to other dimensions of reform. They also felt that gender equality was not being well served in this respect. The evaluation drew attention to the poorly specified gender equality targets that did not reflect the complexity of the subject. As an example, the evaluation indicated that the idea that women should constitute 50 percent of any given target group is a poorly conceived gender equality objective. Thus, the reviewers concluded that the gender equality goals are not sufficiently ambitious and a lack of data means that the gender equality objectives are not being subject to evaluation.

Finally, it is worth noting that from 2014, all information on outcomes and targets at budget chapter level, including gender equality outcomes, and the planned actions at global budget level have been recorded on a dedicated website. This web-based monitoring instrument is updated on an annual basis, allowing developments to be tracked over time (see www.wirkungsmonitoring.gv.at).

\section{B. Belgium}

\section{Summary}

Belgium's gender budgeting initiative is also underpinned by law; in this case the law was introduced to give effect to the country's commitment to gender mainstreaming. Notable in the Belgium case is the specificity of the law which mandates: i) specific methodologies and processes to accommodate gender equality's integration into all budgetary processes; ii) the collection and management of gender relevant data; iii) the specification of gender equality objectives in line with the Beijing Platform for Action (BPfA); and iv) the application of gender budgeting to government procurement. A strength of Belgium's initiative is the alignment of its gender equality objectives with the BPfA, a framework that is comprehensive of all aspects of gender equality relevant to government policy. Implementation of Belgium's multi-faceted and institutional robust gender budgeting program has been hampered somewhat by political discontinuities during the last decade. 


\section{Case study}

Belgium's first activity in the realm of gender budgeting was co-hosting a high level conference on the topic during its tenure as President of the European Union in 2001. Titled "Strengthening economic and financial governance: toward gender responsive budgeting," the conference was co-hosted by the OECD, UNIFEM and the Nordic Council of Ministers and gave rise to a number of gender budget initiatives throughout Europe. Following this, Belgium launched a pilot project to explore the feasibility of applying gender budgeting within all federal government services and activities (Holvoet, 2007). The research element of the pilot was to explore the environment within which budgetary decisions are taken and the level to which existing gender mainstreaming provisions had been applied, in particular in relation to the budget. Of particular interest among the findings is a discussion of the Belgian Development Cooperation Department's use of the OECD's Development Assistance Committee (DAC) Gender Marker, by which gender-related aid spending is tracked by countries. The Gender Marker is a simplistic form of gender budget analysis and is used within the frame of results-based management. Holvoet draws parallels between the Gender Marker and performance based budgeting, a budget process seen as better able to accommodate gender budgeting, than the traditional line item system (Sharp, 2003). Belgium at this time had begun to move toward performance based budgeting. ${ }^{4}$

The pilot, which looked at gender mainstreaming more broadly, paved the way for legislation in 2007 that would effectively institutionalize gender budgeting. ${ }^{5}$ Introduced in fulfillment to a commitment to the BPfA, the law was adopted in line with the EU's developing strategy on gender mainstreaming, rooted in Article 3 of the Treaty of Amsterdam (Joly, 2009). The purpose was "to structurally integrate the gender dimension into all federal policies" (Ibid. p.3).

The law mandates specific gender budgeting processes and responsibilities. In the first instance, the government is required at the beginning of its term of office to identify gender equality objectives. The linking of these objectives with the budget is achieved by the preparation of a "gender note," quantifying the budgetary allocations of each Ministry to their attainment. The gender note, which is to be attached to each draft of the general expense budget, is effectively an accounting instrument, allowing for the calculation of aggregate budgetary spending targeted towards gender equality.

In addition to the gender note, the law stipulates the application of a "gender test": an assessment of the potential differential impact on women and men of all government legislative and regulatory measures presented to the Council of Ministers. An important

\footnotetext{
${ }^{4}$ Troupin et al. (2013) note that, while there is an increased use of performance information, full performance based budgeting is unlikely in the medium-term in Belgium.

${ }^{5}$ The law of January 12, 2007 on verifying the application of the resolutions of the global conference on women held in Beijing in September 1995 and integrating the dimension of gender within the totality of federal policies (Belgian Monitor of February 13, 2007).
} 
element of the law is the mandate to collect and manage sex-disaggregated data and to develop gender indicators.

Two additional stipulations of the law are: i) the make-up and responsibility of an interdepartmental coordination group to guarantee the implementation of this law; and ii) the role of the Institute for the Equality of Women and Men (the Institute) in providing guidance and support. The interdepartmental coordination group was established by royal decree in 2010 and is made up of representatives from each Ministry, high-ranking civil servants from each administration, and staff from the Institute. Finally, the law covers public procurement and the granting of state subsidies.

Article 2 of the legislation specifically mandates the integration of a gender perspective in the budgetary preparations. This article provides the basis for the methodology drawn up by the Institute. The starting place for that methodology was the 2009 budget circular, which indicated the scope of the legislative mandate on gender budgeting and asked all Federal Public Services ${ }^{6}$ to identify budgetary allocations that could be the object of an ex-ante gender analysis with regard to costs. In 2010, the Minister for Equal Opportunities issued a specific circular on gender budgeting, with elaboration of a methodology, designed in collaboration with the Institute. This was supplemented with a manual in 2011. From 2010 on, the annual budgetary circular of the Federal Public Service Budget and Management Control also mentions the obligation of applying the gender budgeting methodology and refers to the specific circular on gender budgeting.

According to the methodology, each Federal Public Service is required to subdivide all budgetary allocations into three categories. Category 1 is concerned primarily with budgetary allocations related to the internal functioning of government, and thus of no relevance to the attainment of gender equality. Examples given in the 2011 manual include operational expenses in information technology, costs for leasing real estate, interest on late payments, and compensation for damage to rental property. Personnel costs (salaries, training costs, etc.) are also included as Category 1, notwithstanding the manual's clear explanation of the gender dimensions of personnel costs and of the potential for making progress on gender equality within the public service by focusing on human resource policy.

Category 2 covers budgetary allocations aimed at achieving gender equality. Here we are talking about programs and services designed to redress the impact of past gender discrimination or to eliminate persistent discrimination. Examples include refuge services for victims of domestic violence, grants to organizations providing services to marginalized women and men, and labor market activation schemes targeted at particular groups of women.

\footnotetext{
${ }^{6}$ Equivalent to ministries or government departments.
} 
No action is required with respect to Category 1 allocations. Category 2 items are to be included in the gender note, specified in the legislation. The gender note is simply a table identifying the action, and the program within which it is contained, the government department or agency responsible for the program and the amount of money allocated to the program. There is no facility to indicate the numbers of beneficiaries of the activity.

Finally, Category 3 allocations encompass public policy measures directed to sizeable populations of society, which are thus likely to have an impact on gender equality. Guidance from the Institute recognizes that Category 3 is the largest grouping of budgetary allocations, thus acknowledging that gender is a determining characteristic when it comes to the impact of public policy. Category 3 items are to be subjected to a gender analysis to establish the relative status of women and men in the domain to which the budgetary item is targeted. This analysis is documented in a "gender comment" and used to inform the implementation of the program to produce a better gender equality outcome.

Within the framework of the budget cycle, when dossier managers request a budget from the "Budget and Management" department of their administration, they indicate the category to which their dossier pertains as part of the justification of basic allocations. It is the responsibility of the Budget and Management department to compile all gender notes and gender comments. The Federal Public Service Budget and Management Control has responsibility to compile gender notes and gender comments at the aggregate level and to append them to the budget documentation.

The most recent Federal Plan on gender mainstreaming (2015-2019) renews the government's commitment to gender budgeting and gives details of each member of government's commitment to integrate the gender perspective in certain of their policies. The Minister of Finance, for example, commits to redressing any gender imbalances in relation to personal income tax, business expense deductibles, and incentives toward savings for pensions. The Minister of Civil Service commits to integrating a gender perspective in the review of pay scales, recruitment, and training procedures and in the development of new forms of working, including teleworking, flexible, and temporary work arrangements. A final example is from the Minister of Justice with a commitment to integrate a gender dimension in the development of prison policy - in particular, policy on the treatment of prisoners. It also commits to take the gender perspective into account in the planned reform of the matrimonial and inheritance law.

The Institute's evaluations have been unable to generate sufficient data to allow it to evaluate outcomes. Instead, the Institute has focused on whether and to what extent the methodologies have been applied. So, for example it reports that the percentage of budgetary allocations not categorized rose from 1.2 percent in 2013 to 8.5 percent in 2015. The Institute sees this as an indication of the methodology not being applied in the case of new budgetary allocations coming on stream when the new government came into power. The percentage of items listed 
as Category 3 items stood at 10.5 percent in 2013 and had decreased to 10.1 percent in 2015 . There was a small increase in Category 2 budgetary allocations, from 0.6 percent in 2013 to 0.9 percent in 2015 . These figures, particularly those related to Category 3 are disappointing, especially given that Category 3 comprises the largest grouping within the budget. Without a full-scale evaluation it is difficult to say what factors are at play. Belgium's political challenges in forming a government have played a role in determining priorities for the Institute. With the formation of a new government in late 2014, the Institute's focus has been on the political level, in the first instance to ensure that decisions are made that will allow gender mainstreaming measures, including gender budgeting, to be enacted according to the mandates, and the spirit of the law.

\section{Sweden}

\section{Summary}

Given their track record on gender equality in general, it is not surprising that the Nordic countries were among the pioneers of gender budgeting in Europe. The Nordic Co-operation ${ }^{7}$ provided the framework for the early initiatives in the region. A joint project was launched in 2004 with Finland, Iceland, Norway, Denmark and Sweden ${ }^{8}$ all undertaking pilot projects over the course of a two-year period.

Following this, each country has charted its own course, ranging from Denmark, where, notwithstanding its stated commitment to gender budgeting, some commentators report that there is little evidence in the policy process; to Iceland where a new 5-year plan is rooted in a legal mandate within the newly adopted Organic Budget Law $;{ }^{9}$ to Sweden, where the newly elected, and self-proclaimed feminist government has reinvigorated its long standing commitment to gender budgeting.

Sweden has for many years been cited as a model of progressive gender equality policy and practice. In particular, it is known for its provision of childcare and other welfare provisions that promote women's economic participation and go some way toward a more equitable division of domestic responsibilities for men. In like manner, Sweden has been to the fore in the area of gender mainstreaming, in particular in the area of capacity building for government officials, the development of methodologies and tools, and the production and management of sex-disaggregated data. Other countries, both within and beyond Europe,

\footnotetext{
${ }^{7}$ The Nordic Co-operation brings together Denmark, Finland, Iceland, Norway, Sweden, the Faroe Islands, Greenland, and Åland to collaborate on numerous regional issues. Its work on gender equality dates to 1974 (Nordic Council of Ministers, 2015).

${ }^{8}$ Sweden had already begun its own pilot projects in 2003 , focusing on programs within the transport, regional development, and social sectors (Schmitz, 2006).

${ }^{9}$ The 5-year plan was adopted by parliament in the summer of 2015 and the Organic Budget Law in December, 2015.
} 
have adopted a number of the analytic and process tools developed in Sweden. Nevertheless, relative to its own standing, Sweden is conscious of the need for improvements and is continuously refocusing its efforts.

Case study

Following elections in September 2014, the new government declared itself a feminist government and, among other gender equality commitments, outlined its intention to institute gender budgeting in the program for government presented to Parliament by the Prime Minister. ${ }^{10}$ It is instructive to understand this commitment to gender budgeting in the context of Sweden's previous efforts to mainstream a gender perspective in its budgetary processes and policies.

Women in Sweden have enjoyed the benefits of individual or separate income tax assessment since 1971. The Equal Opportunities Law, designed to combat discrimination in the workplace, came into force in 1980. Efforts to incorporate a gender equality perspective in Sweden's economic policy date to the late 1980s, and in 1988 a special appendix was introduced into the Budget Bill to show the distribution of economic resources between women and men. Since 2003, this appendix has been attached to the Budget Statement.

Statistics Sweden has had a gender equality unit since 1982, and since 1984 has published Women and Men in Sweden, Facts and Figures at regular intervals. In 1994, the Ordinance on Official Statistics mandated that all official statistics related to individuals are to be disaggregated by sex. A review of the Budget Bill in 2006 found that the use of sexdisaggregated data needed improvement. At the request of the government, Statistics Sweden produced guidance on how to collect and use sex-disaggregated data and provided illustrations of its importance to government policy. The government's objective was to ensure that all tables and graphs related to individuals should be based on sex-disaggregated data in the 2007 Budget Bill (Sweden Government Offices, 2006).

Gender mainstreaming has been in operation in Sweden since 1994. In relation to gender mainstreaming in the budget, the Ministry of Finance initiated the project, An Equal Share, in 2002. This was wound up in 2004 and gender budgeting was subsumed into the new Plan for Gender Mainstreaming, 2004-2009, signaling that gender budgeting was to become part of the regular work of gender mainstreaming. A central goal of the Plan was to integrate a gender analysis into the "two central decision-making processes in the Government Offices - the legislative process and the budget process" (Sweden Government Offices, 2006, p.7). This renewed focus led to the development of a range of methodologies, overseen by the JamStod Committee, ${ }^{11}$ for which Sweden has become renowned and which has been influential across Europe and beyond. A 2006 government bill resulted in the drafting of new

${ }^{10}$ Statement of Government Policy, available at http://www.government.se/informationmaterial/2014/10/statement-of-government-policy-3-october-2014/ 
national gender equality objectives, and in 2007 the new Ministry of Integration and Gender Equality was established (Bjorklund, 2007). Again in 2012 the government produced a fivepart Gender Mainstreaming Plan

To return to the current government's commitment to gender budgeting, it is noted that given its minority status the government did not succeed in passing the 2015 budgetary bill, which would have seen a significant increase in funds to address a number of gender equality related areas.

Nevertheless, in proceeding with the revitalization of gender budgeting per se, the government has identified the analytical tool, JamKas, as its main instrument. This dates from the JamStod work of 2007, but has been updated to accommodate the renewed focus on gender budgeting. The method covers the following activities: i) inventory and prioritization of gender equality relevance; ii) analysis of how gender equality is effected by budgetary item under review; iii) a survey of current gender patterns in the selected program or sector; iv) with reference to national gender equality policy objectives, assess the potential impact of proposals; v) examine alternative solutions if negative impacts are anticipated. The addition of this last step is to underscore the imperative of coming up with a solution, should the initial analysis point to a potential negative impact. The method, which will be applied to all budgetary measures, is based on a gender impact assessment, a commonly used gendermainstreaming tool where the emphasis is on mitigating potential negative impacts. It also encompasses some of the elements of the tools used in Belgium and Andalucía with the focus on determining gender relevance and prioritizing those budget measures with the potential to have the strongest and most immediate impact on gender equality.

From 2016, the annual budget circular will include instructions on the application of gender budgeting throughout the budget process. Among the requirements set out in the circular is that gender impact analysis be carried out at the early stage of new budget proposals. In addition, sex-disaggregated data are to be used and new gender equality indicators devised to reflect current status. This new government initiative is seen as strengthening gender mainstreaming in the budgetary process by improving the mechanisms for internal management and control, an improved methodology (JamKas), and better use of sexdisaggregated data. The initiative should also result in a more advanced gender equality impact analysis.

\section{Finland}

\footnotetext{
${ }^{11}$ JämStöd, the Swedish Gender Mainstreaming Support Committee, was set up in 2005 to support gender mainstreaming within government offices and agencies. It has overseen the development of tools and methodologies which have been adapted internationally.
} 
In Finland, the Ministry of Finance took the decision to adopt gender budgeting and has led the initiative throughout. Under the Nordic partnership project, Finland carried out a Gender Impact Assessment of the budget of the Ministry of Social Affairs and Health. Following this in 2006, the Ministry of Finance issued specific instructions in the budget circular, requiring all Ministries to include a summary of the important gender impacts of measures for each budget chapter. The goal was that the budget should incorporate a gender perspective on the full range of government policies, including regional development, the environment, productivity, poverty, innovation, ageing, and health (Onwen-Huma, 2012).

An assessment of the budget proposal for 2008 reveals that all Ministries made reference to gender equality to some degree or other; one third cited concrete goals and actions; while just one Ministry (Social Affairs and Health) presented its statistics disaggregated by sex. It was clear from this evaluation that there was a need for improvement in the collection and management of sex-disaggregated data, as well on a more focused format for the Gender Impact Assessment. The Ministry of Finance issued more robust instructions to this effect and subsequent budget proposals in 2009 and 2010 showed marked improvements.

The language of Finland's Gender Equality Action Plan, 2012-2015, extends the concept of gender budgeting to an incorporation of the gender perspective in the country's economic policy, presenting the goals of gender equality and economic growth and sustainability as complementary. The action plan is organized around the three strategic objectives of the Program for Government: the reduction of poverty, inequality and social exclusion; consolidation of public finances; and the strengthening of sustainable economic growth, employment and competitiveness. In addition to the ongoing work of gender budgeting, each ministry is mandated to work toward the sustained integration of a gender perspective into at least one of its major policy areas that is clearly linked to the Program for Government.

One report suggests that the incorporation of gender perspective in budgetary processes has become routinized (Valkama, 2009) and an official of the Ministry of Finance concurs by acknowledging that it is now part of the mainstream of government administration (OnwenHuma, 2012). 


\section{E. Iceland}

Iceland's first experience with gender budgeting was a pilot project undertaken within the framework of the Nordic Co-operation in 2006. In 2009 the new coalition government adopted gender budgeting as a key element in the preparation of the budget and of economic policy. To steer its rollout, the Minister of Finance set up a committee with representatives from three Ministries, the Centre for Gender Equality, and the Institute for Gender, Equality and Difference at the University of Iceland. During this period (2010-2011) each government department was obliged to undertake a pilot project with the goal of establishing the scope and parameters of a viable methodology. An attendant goal was to gauge the adequacy of existing gender-related data. These early pilot projects included analysis of the transferability of personal tax discounts between couples by the Ministry of Finance; research on the debt status of Icelandic households by the Ministry of Economic Affairs; and analysis of the gender distribution of unemployment benefits and hospital waiting lists by the Ministry of Welfare.

The government approved a 3-year Plan for Gender Budgeting in 2011, which had been drafted by the Steering Committee. Under the plan, Ministries were to choose one main policy area with which to work and to continue with pilot projects. In its recommendation with respect to how to apply gender budgeting, the Steering Committee was keen to emphasize the centrality of gender considerations to all fiscal policy making. It placed particular emphasis on measures designed to bring about economic recovery and the need to apply gender budgeting tools to planned public expenditure cuts as well as to job creation measures (Iceland, Government of, 2011).

Article 16 of the Equal Status Act (2008) mandates the use of sex-disaggregated statistics in all official economic surveys and in subsequent reports and policymaking. Within the threeyear gender budgeting plan, the Steering Committee emphasized the need to expedite the collection and management of sex-disaggregated statistics.

In late 2015, the government approved a new five-year plan on gender budgeting with the overall objective of making the methodologies associated with gender budgeting more integral to the decision-making process within government. The new plan has three broad emphases:

- A focus on measuring short term outcomes and amending plans to ensure that targets are reached;

- gender impact analysis of all new budget proposals; and

- analysis of all new legislative proposals to include a cost-benefit analysis from a gender perspective.

While the new plan does not make specific mention of tax policy, this dimension is covered by the gender analysis of new legislative proposals. 
The new five-year plan follows the government's gender equality targets. This includes a joint gender equality goal for all Ministries, as well as individual gender equality goals for each ministry. ${ }^{12}$ The first year allows for an audit of available sex-disaggregated statistics, while the second year is given over to identifying priority issues and elaborating gender equality targets. The make-up of the Steering Committee has changed to include representatives from all Ministries and the Centre for Gender Equality. It no longer includes the representative from the university, thus excluding civil society from this position.

To bolster the new gender budgeting plan, the new organic budget law, which came into effect in January 2016 assigns responsibility for gender budgeting to the Minister of Finance, who is to work in consultation with the Minister for Equality to elaborate the specifics of the gender budgeting program and to oversee its implementation. In addition, the organic budget law mandates that gender budgeting is to taken into account in drafting the Budget Bill and that the Budget Bill shall detail the impact of the budget on the attainment of gender equality targets. Instructions on gender budgeting have been included in the Budget Circular since 2010.

\section{F. Berlin}

The administration of the federal state of Berlin is organized on two levels, with nine State Ministries and 12 district councils. In line with Germany as a whole, Berlin operates the traditional cash-based, line item, input-oriented budgeting, generally referred to as cameralistic (Jones and Luder, 2011). This is supplemented by a focus on "product" or output budgeting, which was introduced at the national level as part of a budget reform process in 2009. Product budgeting is a step toward program budgeting, allowing for a limited view of the benefits the budget is "producing" for the public in terms of measurable outputs. It has been adopted by a number of federal states as well as by lower levels of local government in Germany. However, while product information is presented in the Berlin budgets, parliamentarians favor the more detailed traditional line item budgeting which allows appropriations to be tracked by sector, by geographical region and by input and thus also allows for a greater degree of steering.

In Berlin, gender budgeting has been in operation as tool of gender mainstreaming since 2003, following a decision by the Berlin House of Representatives in 2002. The adoption of gender budgeting was due in large measure to the support of and promotion by women parliamentarians and to its promotion by an active civil society initiative. While responsibility for gender mainstreaming belongs with the Senate Department for Labor, Integration and Women, it is the Department of Finance that takes the lead on gender

\footnotetext{
${ }^{12}$ Gender equality targets had not been elaborated at the time of writing.
} 
budgeting. For day-to-day operations, a working group, hosted jointly by both departments, coordinates the process.

In the beginning the objective was to render the budget transparent in terms of a genderdifferentiated use of public finds. The approach was piloted with an application on institutional transfers at the Land level and at the district level on 56 products of the budget. Sex-disaggregated data was incorporated into the budget documentation for the 2005 and 2006 budgets. Following further decisions by the House of Representatives, the analysis was extended to take account of secondary beneficiaries. The House also wanted to deepen the gender analysis, beyond accounting for the numbers of male and female service beneficiaries. The third stage of the model employed in Berlin moves toward being able to "steer" or reorient budgetary expenditure toward the achievement of specific gender equality objectives. The goal is the full integration of gender budgeting as a steering mechanism into the parliamentary budget process.

The interdepartmental gender budgeting working group has been meeting regularly since 2003. In the early years, in addition to senior personnel from both Senate departments, the group also included representatives from civil society. Current senior personnel in both departments speak to the very positive collaborative work over the years. By 2011 budget makers perceived an impasse in that they lacked the capacity to make the changes that would bring about a better gender equality outcome. Up to this point, they had been tracking the numbers of beneficiaries of public services, disaggregated by sex. However, they lacked the capacity to contextualize these numbers so as to assess whether or not they represented a gender imbalance and to what degree. Without access to other sources of information and expertise, their ability to work towards gender equality outcomes was limited. In line with this, officials commissioned a new tool which enables them to tap into other sources of information and to articulate that information in a format that would help them to identify where they have room to influence budgetary outcomes.

The most recent budget for the Senate of Berlin (2016/17) demonstrates the enhanced level of gender-related information used within the budgetary process. In particular, it shows evidence of the use of the new "steering" tool introduced in 2013. We use as our example the budget of the Senate Department of Labor, Integration and Women. The opening chapter, which deals with departmental objectives and priorities, a breakdown of revenue and expenditure and other general considerations, has a section outlining the role of gender budgeting in the budget. This states that not only is gender budgeting important to the goal of gender equality, but has also become a "Ministerial control function" that complements the "principles of sustainable fiscal policy" by helping to ensure public resources are targeted efficiently (Senate DLIW, Berlin, 2016/17).

Each chapter of the budget begins with a sex-disaggregated breakdown of public officials employed by the division of the Department with which the chapter is concerned. In addition, 
the mean monthly salary is disaggregated by sex and gives an indication of the gender gap in salary. This is accompanied by an explanation for the gender gap. The explanation points to the predominance of men in the higher salary brackets and to women having to take maternity leave and so interrupt their career progression.

The use of the "steering tool" is most evident where there is a breakdown of expenditure on services that are contracted out and also in relation to subsidies and grants to nongovernmental organizations serving the needs of particular sections of the community. Services range from return-to-employment training schemes, advice and information to migrants, supports for women starting up small businesses and women's refuge facilities. The budget shows the number of beneficiaries, disaggregated by sex, indicating a trend over a three-year period and project targets for the ensuing two years. Analysis of the data indicates whether the sex-distribution of beneficiaries matches the actual target group and if not, what measures are planned to "steer" the outcome to achieve gender equality. An analysis of the effectiveness of the new tool is outside the scope of this paper. However, there is evidence of the gender analysis being weak in places. Nevertheless, the availability of this type of information within the budget represents progress and can serve as a basis for deeper analysis in the future.

Berlin officials are very proud of their gender budget orientation; they view it as part of their modern approach to budgeting and are involved in delivering seminars on their progress in a number of other countries, as well as hosting study visits on the subject. In accounting for their success, Berlin officials point to a clear mandate from parliament and the Berlin Senate; formal structures, with the Ministry of Finance in the lead role; a collaborative approach with an emphasis on learning by doing; and year-on-year reporting as part of the annual budget process. The amount of gender information incorporated into the budget has increased every year, providing evidence of the sustained political and bureaucratic commitment.

Nevertheless, there is some concern that the new steering tool has not yet gone far enough to move the Berlin approach qualitatively beyond disaggregating beneficiaries by sex. This has been the approach for ten years and the challenge now is expanding a methodology that has already become institutionalized and "locked in" its own path dependency. Dr. Gabriele Kämper, Head of the Equality Division in the Senate Department for Labor, Integration and Women, points to the challenge that the gender expertise resides within her Department, which is one part of the ministerial collaboration coordinating gender budgeting, even though the day-to-day operations fall to the Senate Department of Finance, where the officials, while enthusiastic about gender budgeting, lack the gender expertise needed. Notwithstanding the significant level of collaboration, the balance of decision-making power remains with the budget officials and the challenge of bringing them to a level of gender competence persists.

On the other hand, a clear strength of the Berlin initiative is its political underpinning and its endurance over a period of 12 years. This has resulted in a collaborative process that is now 
well established and thus the concept of gender budgeting is no longer a contested principle, as it is in other parts of Germany and indeed in Europe.

\section{Gender budgeting in Germany}

It is worth considering Berlin's gender budgeting initiative in the context of the rest of Germany. On aggregate, there is a significant level of gender budgeting activity at Land, district, and municipal level, but none at the central level. Germany is, however, one of the few countries to have commissioned a national level feasibility study on gender budgeting, and while it did not move forward on the recommendations of the study, it did leave open the possibility of revisiting the subject. Specifically, the official response called for "further fundamental clarification" and suggested that should the federal government again consider budget reform, the relevance of gender budgeting might best be assessed in that context (Färber, 2006). In addition, the Federal government maintains that government departments are responsible for gender equality objectives within their respective remits and that these should be reflected in their resource allocations. It is worth noting that in July, 2015, the Budget Committee of the German Bundestag convened a hearing on gender budgeting to review activity since the feasibility study and examine potential opportunities.

A recent study, looking at the different paths taken by Austria and Germany in relation to gender budgeting, suggests that the interaction of a number of factors shaped the different outcomes in both cases: i) the absence of an on-going administrative reform process meant that Germany could not avail of the opportunity which allowed the Austrian government to "piggy-back" its more political gender budgeting innovation onto a seemingly managerial/technical innovation; ii) Germany's budget is fundamentally oriented toward the household (the German word for budget is the same as for household: Haushalt), as evidenced most clearly in its tax and welfare regime, thus rendering the concept of gender equality - with its insistence on looking at individual behaviour within the household - as foreign and untranslatable; and iii) Germany's federal system devolves the delivery of public services to the lower levels of government and, given that gender budgeting is most closely associated with a more targeted (and equitable) distribution of public expenditure, the national government could likewise devolve gender budgeting (Quinn, 2015).

\section{G. Andalucía}

Gender budgeting in Andalucía has a strong legal basis, beginning with a 2003 law on Fiscal and Administrative Measures and reinforced over the years by other primary legislation and regulations. The 2003 law established two gender budget provisions: firstly, the requirement that the regional budget presented to parliament contain a Gender Impact Report and secondly, the setting up of a Gender Impact Commission (an interdepartmental coordinating body, composed equally of women and men) within the Ministry of Finance to oversee the execution and approval of the Gender Impact Report. Also of particular importance is the 2007 law on Gender Equality, Article 8, which regulates the mandatory publication of the 
Gender Impact Report for the draft finance bill; and Article 10, which calls for the collection and management of sex-disaggregated and gender relevant data. The Finance Law of 2010 mandates that the Gender Impact Report be attached to the annual budget law. In addition, further government decrees solidify the role of the Gender Impact Commission. Finally, the Statute of Autonomy mandates the application of a Gender Impact Assessment for all new laws and provisions, including the finance bill.

As with Berlin, gender budgeting is seen as the primary vehicle for implementing gender mainstreaming in Andalucía. In addition, the regional government, keen to succeed as an autonomous region, and in particular to reverse the fortunes of one of the poorest regions in Spain, has adopted gender budgeting as part of its strategy for economic growth and competitiveness (O'Hagan, 2014). In effect, gender budgeting is perceived as a tool of modern governance. ${ }^{13}$

The first Gender Impact Report was produced in 2005, but was for internal use only and therefore not published. In 2007 the G+ Program was introduced. It is presented as a threestage methodology, and key to its operation is the first stage of identification and classification of budgetary programs according to the $\mathrm{G}+$ scale. The aim is to prioritize those budget programs that are most relevant to and capable of advancing gender equality. All budget programs are ranked from $\mathrm{g} 0$, for those deemed not gender relevant, to $\mathrm{G}+$, for those seen as having the most potential to effect gender equality.

While each department is responsible for classifying its programs, the Gender Impact Commission must approve them. Once classification is in place, the second stage of the $\mathrm{G}^{+}$ Program comes into play, whereby a Strategic Guidance Document (DOE G+) is drafted for each budgetary program (with the exception of those ranked g0). Made operational in 2010, the DOE G+ acts as a "living" document, a record of early analysis and gender related treatment of the program to include objectives and indicators, as well as details of how results are evaluated. The idea is to maintain and update the document year on year.

The Gender Impact Report of the 2010 budget points to significant progress towards the standardization of a system of analysis within the day-to-day operations of each agency. Among the achievements listed is a decrease in the number of budget programs designated as having no gender relevance, an increase in the number of indicators-21 more gender equality indicators between 2009 and 2010 - and the quality of those indicators.

The Andalucía gender budgeting exercise is notable for the roundedness of organization. The Ministry of Finance has taken the lead since its inception, initiating an ongoing deepening of the methodologies and processes and ensuring the integration of the practice within the regular budgetary institutions. In addition to tools and systems, there is a keen awareness of

\footnotetext{
${ }^{13}$ Aguilera Diaz, Del Olmo Garrudo, and Escobar Arroyo (2011).
} 
the need to change the work culture within the administration and to ensure adequate gender related expertise. In line with this, an organizational change process underpins the shift to gender budgeting with a focus on changing values, priorities and stereotypes and the provision of expert technical assistance. This is resourced by the introduction in 2010 of the G+ Fund. As of September, 2015, the Ministry of Finance claims that upwards of 50 percent of those in charge of budgets have been trained in the use of sex-disaggregated data. In addition, an audit of staff in 2012 revealed that 93 percent of Ministry of Finance staff knew of gender budgeting, and 64 percent knew of one of more tools. However, only 30 percent of staff directly involved in budgeting activities knew of the $\mathrm{G}+$ scale rating of their program.

Gender budgeting in Andalucía does not cover the revenue side of the budget. This is primarily because there is little revenue competence at the regional level. Nevertheless, the 2012 Gender Impact Report presents a breakdown of regional taxes and tax credits indicating the number of women and men who paid or benefited respectively.

It is important to note that the Gender Impact Report does not analyze the impact of the budget on gender equality. That is to say, it does not record the degree to which gender equality objectives attached to budgetary programs met their goals. It is in effect a status report on gender equality, to include developments that have taken place in the year being reported on. Following an introduction, the report is organized according to an adaptation of the $3 \mathrm{R}^{14}$ gender audit methodology: titled "Reality," a section deals with the reality for women and men in Andalucía, that is to say by sector and/or theme (e.g., health, education, employment, work/family life balance, etc.); the next section is "Representation" and covers a gender analysis of public sector employment; and the final section sets out the measures specified in the upcoming budget to address gender inequality. All regional ministries are covered in this final section, and each budgetary program is dealt with. Given all of this, however, it has to be noted that rather than specifying gender equality objectives and targets, the commitment to gender equality for the next budgetary period is expressed in terms of the application of gender mainstreaming tools and processes.

It is also worth noting that while close to 75 percent of budgetary programs are now ranked as $\mathrm{G}+$ in terms of their potential to effect gender equality, this is not say that these programs deliver on their gender equality potential. Nevertheless, recognition of gender relevance within the framework of the budget is an important step toward achieving better gender equality outcomes through the budget.

In 2013, the provision for gender audits (evaluations) contained in the 2003 Fiscal Measures

\footnotetext{
14 This is a Swedish gender mainstreaming tool and has become popular throughout Europe and beyond. It has also been updated to a 4R method to accommodate gender budgeting by looking at resources. See http://www.includegender.org/toolbox/map-and-analyse/4r-method, last accessed on September 11, 2015.
} 
Law was enacted. Five $\mathrm{G}+$ programs ${ }^{15}$ were assessed in terms of effectiveness in attaining gender equality goals, as well as the degree to which the associated processes of planning, and implementation were gender mainstreamed. A report of the results published in October 2015 concludes, "gender mainstreaming in the budgeting process and activities has increased during the period 2009-2012 in relation to the work existing prior to this date" (Gualda Romero, Aguilera Diaz, and Cirujano Campano, 2015). In this respect four of the programs use sex-disaggregated data and four have provided gender related training to their staff. However, only one of the programs carried out a gender analysis of its target population. The report is less clear on hard data obtained from measuring actual outcomes. A 2013 audit points to more places for nursery aged children in state schools, an increase in women entering self-employment and cooperatives, an increased focus on combating violence against women, and an increase in the employment rate among women in rural areas as well as the number of women in positions of responsibility.

The current audit for the period 2015-2016 is evaluating the impact of 26 budget programs. An important follow-up to the audit process will be the planned public consultation process. Those charged with oversight of the gender budgeting process acknowledge the need to engage with civil society, a dimension which to date has been missing in the Andalucía exercise.

Results reported elsewhere include: an expansion of the after school services for children; an increase in female ownership of agricultural holdings; a top-up from the Regional Government of the State pension and an increase in female university professors from 13 percent in 2008 to 20 percent in 2015 (Gender Impact Report, 2016). As of 2014, women occupied 51 percent of senior positions within the administration of the Regional Government; 33 percent of the positions on the High Court and 42 percent of posts in the municipal councils (Gender Impact Report, 2015).

Of particular pride and satisfaction to the Ministry of Finance is the advance made with respect to data. Of 282 statistical activities undertaken through the Statistics and Cartography Program for 2012, 129 are disaggregated by sex. Almost 75 percent of budget staff incorporates sex-disaggregated data into their reporting. The use of gender-relevant indicators has increased year on year, with over a 22 percent increase in the number of indicators used for the 2015 budget compared to the 2014 budget.

\footnotetext{
${ }^{15}$ Development Aid, of the Regional Ministry of Local Administration and Institutional Relations; Creation and Dissemination of Statistical and Cartographic Data, of the Regional Ministry of Economy, Research, Science and Employment; Early Childhood Education, of the Regional Ministry of Education, Culture and Sport; Healthcare Provision by the Andalucian Health Service, of the Regional Ministry of Equality, Health and Social Policy; and Rural Development, of the Regional Ministry of Agriculture, Fishing and Rural Development.
} 


\section{Case Studies of Gender Budgeting Initiatives in Emerging Markets}

\section{A. Albania}

\section{Summary}

Albania's gender budgeting initiative is driven in large measure by its candidacy for the European Union and support from UN Women. It is also strongly influenced by the model in place in Austria. Both these factors give cause for caution regarding the sustainability of the project, once EU membership is attained and external support is no longer available. As a candidate for EU membership, the country has been working toward the restructuring of its economy and the reorganization of its administration in accordance with EU agreements. Albania, like Austria, has been reforming its budget institutions, moving to a medium-term expenditure framework and to results-based budgeting. With its focus on the modernization of many other policy frameworks, including those associated with Employment and Social Affairs Chapter of the acquis communautaire, the government adopted a decision on gender budgeting as a way of satisfying a number of commitments.

A strength of Albania's initiative is its alignment with the government's gender equality strategy. Thus, for the first round of implementation in 2015, nine gender equality objectives with associated budgetary allocations have been identified and closely match objectives in the National Strategy for Gender Equality and Eradication of Gender Based Violence and Domestic Violence 2011-2015. Table 4 provides a breakdown of budgetary allocation by government department and program.

\section{Case study}

The Council of Ministers of the Republic of Albania adopted Decision nr. 465, "Decision on the Introduction of Gender Mainstreaming in the Medium Term Budget Program," in July 2012, designed by an international gender budgeting expert in collaboration with a national budget expert. This became the legal basis for the introduction of gender budgeting. The Decision is another part of the Government's strategy on gender equality. A parallel process is the integration of gender mainstreaming principles and objectives in the National Strategy for Development and Integration, a project undertaken in the summer of 2012 in collaboration with the Department of Strategy and Donor Coordination. ${ }^{16}$ The Decision can also be seen as part of the Government of Albania's ongoing administrative reform process.

\footnotetext{
${ }^{16}$ Now the Department for Development Programming, Financing and Foreign Aid.
} 
Table 4. Albania: Gender Budgeting Programs, Budget, 2015

\begin{tabular}{|c|c|c|c|c|}
\hline Ministry & Program & $\begin{array}{l}\text { Gender Equality } \\
\text { Objective }\end{array}$ & $\begin{array}{l}\text { Budget } \\
\text { Allocation }\end{array}$ & $\begin{array}{c}\text { Total } \\
\text { Program } \\
\text { Budget \% } \\
\end{array}$ \\
\hline $\begin{array}{l}\text { Agriculture, Rural } \\
\text { Development and } \\
\text { Water Administration }\end{array}$ & $\begin{array}{l}\text { Rural } \\
\text { Development }\end{array}$ & $\begin{array}{l}\text { Subsidies to female } \\
\text { household farmers }\end{array}$ & 100m LEK & 3.25 \\
\hline $\begin{array}{l}\text { Agriculture, Rural } \\
\text { Development and } \\
\text { Water Administration }\end{array}$ & $\begin{array}{l}\text { Agricultural } \\
\text { Information } \\
\text { and Advisory } \\
\text { Services }\end{array}$ & $\begin{array}{l}\text { Information and advice to } \\
\text { female household farmers }\end{array}$ & 20m LEK & 7.6 \\
\hline $\begin{array}{l}\text { Social Welfare and } \\
\text { Youth }\end{array}$ & $\begin{array}{l}\text { Employment, } \\
\text { Qualification } \\
\text { and } \\
\text { Vocational } \\
\text { Education }\end{array}$ & $\begin{array}{l}\text { Vocational education and } \\
\text { training for females; } \\
\text { employment schemes } \\
\text { supporting female job } \\
\text { seekers }\end{array}$ & 10m LEK & 2.7 \\
\hline $\begin{array}{l}\text { Social Welfare and } \\
\text { Youth }\end{array}$ & $\begin{array}{l}\text { Social } \\
\text { Inclusion }\end{array}$ & $\begin{array}{l}\text { Policy support for gender } \\
\text { related issues }\end{array}$ & $11 \mathrm{~m} \mathrm{LEK}$ & 10.7 \\
\hline $\begin{array}{l}\text { Social Welfare and } \\
\text { Youth }\end{array}$ & Social Care & $\begin{array}{l}\text { Services and financial } \\
\text { support to females and } \\
\text { female households in } \\
\text { financial distress, abuse, or } \\
\text { member of marginalized } \\
\text { social group. }\end{array}$ & 90m LEK & 0.4 \\
\hline European Integration & $\begin{array}{l}\text { Institutional } \\
\text { Support for } \\
\text { EU Integration } \\
\text { Process }\end{array}$ & $\begin{array}{l}\text { Ensuring equal rights/ } \\
\text { Opportunity to being } \\
\text { informed about EU } \\
\text { integration process. }\end{array}$ & $28.7 \mathrm{~m} \mathrm{LEK}$ & 6.6 \\
\hline Culture & $\begin{array}{l}\text { Art and } \\
\text { Culture }\end{array}$ & $\begin{array}{l}\text { Equal opportunities and } \\
\text { rights in accessing specific } \\
\text { programs and projects }\end{array}$ & 10m LEK & 1.2 \\
\hline Interior Affairs & $\begin{array}{l}\text { State Police } \\
\text { Support } \\
\text { Services }\end{array}$ & $\begin{array}{l}\text { Equal opportunities in } \\
\text { enrollment to programs }\end{array}$ & 23.3m LEK & 1.9 \\
\hline $\begin{array}{l}\text { Economic } \\
\text { Development, Tourism, } \\
\text { Trade and } \\
\text { Entrepreneurship }\end{array}$ & $\begin{array}{l}\text { Support for } \\
\text { Economic } \\
\text { Development }\end{array}$ & $\begin{array}{l}\text { Financial support schemes } \\
\text { for female entrepreneurs }\end{array}$ & 110m LEK & 9.0 \\
\hline
\end{tabular}

In this respect, it is interesting to note that part of the stimulus for this Decision was a study visit to Austria in September 2011 to explore how Austria established the legal basis for gender responsive budgeting as part of its comprehensive budget reform process. Reform of the budgetary process had been underway in Albania for some years. In 2005, the Integrated Planning System was introduced, a framework that aimed to ensure that core policy and financial processes developed by the government functioned in an integrated manner. These core processes are: i) a National Strategy for Development and Integration, which establishes 
the government's medium to longer-term goals and strategies for all sectors; and ii) a medium-term budget program, which requires each ministry to develop a three-year rolling plan for the delivery of program outputs within each ministry's expenditure ceiling, as set out in the government's fiscal plan. In 2008, a new organic budget law ushered in an ambitious reform of the budgetary process. Among other provisions, the organic budget law: i) calls for a mid-year review of the budget process; ii) sets out more fully the budget preparation and monitoring calendar; iii) identifies roles and responsibilities more clearly; iv) establishes a framework for budget management delegation; and v) introduces further transparency mechanisms through requirements to publish a medium-term budget plan and progress reports on the government website.

Decision 465 draws its legal basis from the Law on Management of the Budgetary Systems, It provides for a number of actions to be taken by the administration in the preparation of the Medium-Term Budget Program. They are: i) the identification of gender equality objectives with targeted outcomes and indicators; ii) the setting of gender equality criteria for the distribution of Regional Development Funds; ii) the alignment of gender budgeting with the National Strategy on Gender Equality; iv) ministerial responsibilities for implementation, and v) a strategy to roll out gender budgeting across all line ministries by 2013 .

In September 2012, UN Women provided training on how to implement Decision nr. $465 / 2012$, and commissioned the development of a guide for government officials. Both took careful account of the new budget institutions in place since the introduction of program budgeting. Thus the methodology developed sought to integrate gender as a category of analysis within the structures and processes in use for the preparation and management of the medium-term budget plan.

An important development was the integration of gender budgeting in the Public Finance Management (PFM) Strategy, 2014-2020. The strategy specifically addresses performancebased monitoring of public expenditure. As of 2014, all Ministries are mandated to identify gender equality objectives - and corresponding measures and activities - within their annual budget plans. Making gender budgeting a standard element of the performance monitoring process should maximize the opportunity for the elaboration of meaningful and measurable gender equality objectives. In addition, the enhanced focus on gender indicators will improve accountability.

\section{B. FYR Macedonia}

\section{Summary}

Like Albania, the former Yugoslav Republic of Macedonia (FYR Macedonia) gained candidate status to the European Union in June 2014. The same UN Women regional program also supports its gender budgeting initiative. The initiative was given its first impetus in the 2012 legislation on equal opportunities between women and men. That law 
signaled the preparation of a Strategy on Gender Responsive Budgeting. It is, therefore, a very young initiative. The Macedonian civil society organization, Akcija Zdruzenska, has expressed some concern that the government has failed to introduce a promised decree that would have put gender budgeting on a more sound legal footing. Nevertheless, the government has adopted a methodology for gender budgeting and has put in place an array of supports and specified a number of government-wide gender budgeting tools. Implementation is planned over a number of phases, with the second phase beginning in 2017 and a third phase in 2019. In addition, UN Women in Macedonia is supporting an ambitious project to build the capacity of a number of civil society groups at local level, to carry out gender analysis on the budget and to engage with government on the basis of that analysis.

Case study

The concept of gender budgeting was first referenced in the FYR Macedonia in the National Action Plan for Gender Equality, 2008-2012. Early initiatives focused on gender budget analyses of a number of key policies and programs with particular relevance for gender equality, including employment, social protection, the self-employment program, the Human Rights program, the program for ICT development, and the rural development program. In July 2012, the government published a Strategy on Gender Responsive Budgeting, which had been developed by senior government administrators with technical support from UN Women. The legal basis for the Strategy is contained in the Law on Equal Opportunities for Women and Men, adopted by the Assembly earlier that year. It is further regulated by the Strategy on Gender Equality, 2013-2020. The principal provisions of the Strategy on Gender Responsive Budgeting include a mandate for the systematic inclusion of equal opportunities in all budget processes; the setting up of an oversight committee; the requirement to consult with civil society in relation to how gender equality can be achieved through the budget; and a call that all data gathered by state agencies should be disaggregated by gender.

The Strategy is focused on three strategic areas: i) introducing a gender perspective in the programs and budgets at central and local level; ii) improving the legal framework for the inclusion of gender responsive budgeting; and iii) strengthening the institutional mechanisms and capacity building that are required for incorporation of the gender perspective in the creation of policies and programs and related budgets. Within this framework, the document sets out a comprehensive set of activities with assigned responsibility and a set timeframe.

As part of the preparation for the Strategy, the Ministry of Labor and Social Policy in 2012 commissioned an analysis of reforms in budgetary policy. The FYR Macedonia had begun a shift toward program-based budgeting in 2008 . The analysis revealed a number of weaknesses, including limited capacity of budget users in relation to strategic planning, identification of indicators and analysis of performance. An overarching challenge is the practice of tabling budget amendments in the middle of the fiscal year. Clearly this affects the realization of targets; indeed, it impacts the process of setting targets because budget 
users anticipate budget amendments that will change the amount of funds available for their programs.

The analysis identified entry points for gender budgeting in the budget process. In the short term the obligation to introduce instructions for gender budgeting was included in the Handbook on Strategic Planning and in the Budget Circular. The Ministry of Labor and Social Policy was tasked with leading out on gender budgeting. A number of programs and sub-programs in the Ministry of Labor and Social Policy, the Ministry of Agriculture, Forestry and Water, the Employment Agency of the Ministry of Labor and Social Policy and the Ministry of Health were chosen as pilot exercises for the purposes of developing sexdisaggregated output indicators. Long-term recommendations in the Strategy cover mechanisms for ongoing oversight by parliament, transparency and review, participation of civil society and capacity building for budget users.

An early assessment of the Strategy during the period July 2012-November 2013 by Akcija Zdruzenska points to little measurable progress. A further review, cited within the framework of the European Commission's Exchange of Good Practices on Gender Equality, notes that the 2014 budget does not contain any information on sex-disaggregated output indicators. It also reports that there is no information available to determine if the pilot projects were in fact implemented.

It has to be said, however, that 2014 was very early to attempt to assess what is in effect a significant policy innovation. Having taken time to scope out the readiness of the environment in terms of data availability and determining the relevance of budgetary programs, the government's methodology signals a new start date for gender budgeting. Four institutions selected in 2013 will pursue a gender budgeting approach through the course of a medium-term budget cycle of three years, concluding in 2016. An additional four institutions selected in 2014 will run to 2017.

One area of particular importance in FYR Macedonia is rural development. In preparation for the rollout of gender budgeting, UN Women commissioned a study to look at how rural women fared in terms of government policies and services and the extent to which women were in receipt of grants and subsidies. Findings show that analysis to differentiate the needs of men and women, undertaken to inform the development of the National Strategy for Agriculture and Rural Development, was not reflected in the Strategy's objectives. Despite this, women have benefited indirectly from measures aimed at improving agriculture technology and market efficiency. Policy incoherence in selection criteria for grants and subsidies means that while women are given an automatic ten-point lead, they can then be denied eligibility altogether because they do not own property. Not owning land is the biggest obstacle to women accessing grants and subsidies; a complex application process and a system of communication of the schemes that favors men are additional challenges. The 
recommendations point to infrastructural needs in rural areas that would benefit women including construction of sidewalks and shelters at bus stations, and improving water supply.

The Ministry of Labor and Social Policy has responsibility for the coordination of gender budgeting throughout the administration, including reporting annually to the government. An Interdepartmental Advisory and Consultative Group provides support and guidelines and plays a monitoring role alongside the Ministry. The Ministry of Finance has included an instruction on gender budgeting in its Budget Circular and is responsible for reviewing the Gender Budget Statement submitted by the pilot institutions. The Gender Budget Statement is to contain analysis from a gender perspective of the selected program and specify a target that represents an improved gender equality outcome, with appropriate indications. UN Women has engaged an external consultant to provide support and gender expertise to participating ministries.

A strength of gender budgeting in FYR Macedonia, as with Albania, is that the institutions chose budgetary programs in line with the government's gender equality objective. In this way the analysis - including targets and indicators - used to determine the government's gender equality objectives can form the basis of the analysis for the gender budgeting exercise. Similarly, progress can be measured against the concrete objectives.

\section{Ukraine}

\section{Summary}

There have been a number of gender budgeting initiatives in Ukraine since 2003. Currently, Sida, the Swedish Development Agency, is resourcing a five-year program. The Ministry of Finance is leading the initiative, which is being supported by a significant complement of international and national gender budgeting experts. The initiative is notable for the level of resources being provided to it by Sida over a five-year period. This timeframe should facilitate the bedding down of relevant processes and it should also allow budget personnel to gain experience in gender budget analysis. It is also notable for its intention to build on previous experience on gender budgeting in Ukraine, at both national and regional level.

\section{Case study}

A range of donors, including UN Women, Sida, the European Union and the Friedrich Ebert Foundation has supported gender budgeting in Ukraine since 2003. Much of the early work was focused at the oblast level with the objective of demonstrating the relevance of a gender perspective through the analysis of selected budgetary measures. Engagement with civil society was, and remains, an important element. In this respect, Ukraine's experience with gender budgeting, in particular the early work, is a good example of the use of gender budgeting to activate and empower civil society toward democratic engagement and gender equality reform. 
UN Women (then UNIFEM) began its work on gender budgeting in Ukraine in 2008 within the framework of the UN/EC Partnership for Gender Equality and Peace. In 2012-2013, UN Women partnered with the Friedrich Ebert Foundation within the framework of the program "Increasing Accountability for Financing for Gender Equality" to support gender budget initiatives at both local and national levels. Prior to this partnership, the Friedrich Ebert Foundation worked at the local level, where the needs of citizens - including the gendered needs - are more visible. The project encouraged the participation of citizens, who launched a lobbying campaign, using gender budget analysis of health and education programs. The campaign succeeded in securing ring-fenced funding for health and education priorities.

In parallel to local level work, national gender budgeting experts worked to introduce gender budgeting at the national level by developing gender indicators. As a way of consolidating gender budgeting expertise, UN Women and the Friedrich Ebert Foundation established a network of gender budgeting experts. The Bureau of Gender Strategies and Budgeting gained official recognition and began with ten experts from the cities of Poltava, Zhitomir, Kharkiv, L'viv, and Lutsk.

Other initiatives associated with ensuring financing for gender equality include the work done by UN Women with the Ministry for Social Protection to develop a methodology to analyze the economic effect of gender policies. The study, which is ongoing, is attempting to track budget allocations to gender equality activities in all 27 regions. An objective of the study is to develop mechanisms to measure the economic impact of spending on gender equality.

Similar work on identifying budgetary investment in gender equality had been carried out by the Women's Consortium of Ukraine in 2011. They focused on documenting the trend in funding for gender equality from all three levels of budgets - national, regional and local during the period 2007 to 2010 . Up to 2008 there was a modest growth in the amount allocated to gender equality activities, but in 2009, funds were cut by between 25 percent and 50 percent, mainly reflecting the global economic crisis. It was also noted that throughout the period 2007-2010, the total amount allocated was 40-50 percent of what had been costed as having been necessary to deliver the programs (Women's Consortium of Ukraine, 2014).

Also of significance to the pursuit of a gender budget approach is UN Women's analysis showing that as of 2012 gender had been mainstreamed into 10 percent of 244 officially registered development projects. This study looked at 33 international non-profit development agencies and found that 12 of these ran specific gender projects, while three other agencies allocated a share, ranging from 2 to 12 percent, of project funding toward better gender equality outcomes.

Current work on gender budgeting is taking place primarily within the framework of a fiveyear project — "Gender Budgeting in Ukraine" — funded by Sida. In addition, UN Women 
and the Friedrich Ebert Foundation have an ongoing program on gender budgeting. The Sidafunded program is arguably the best-resourced initiative on gender budgeting to date in Ukraine, encompassing a five-year time-frame, with a significant staff complement and associated resources. A previous Sida pilot project, which ran from 2011 to 2012, targeted two oblasts and focused on Youth and Education in one, and Sports and Physical Culture in the other. As a result of the level of awareness of the potential effectiveness of gender budgeting, accumulated over a number of years of projects, the Minister of Finance approached Sida to request a bilateral cooperation in implementing gender budgeting as part an ongoing budget reform.

The gender budgeting project has been designed to align with current budgetary and public administration reform work in Ukraine. Three aspects of the reform agenda have particular relevance to gender budgeting: i) achieving the level of the acquis in relation to human rights and equality; ii) budgetary reform; and iii) decentralization of government to the regional and local levels. All aspects of the reform have come into sharper focus with the signing in 2014 of the Association Agreement with the EU. Major public finance reform projects have been underway for some time, including a World Bank-funded public financial management project aimed to improve operational efficiency and transparency. Ongoing reform projects include shifting to results-based budgeting, making more evident the links between government policy targets and budget targets, and renewing the focus on medium-term financial planning. The latter is intended to improve the links between financial resources and priority tasks, which in turn should improve the prerequisites for the provision of public goods such as education and social services.

Within this framework of public financial management reform, the overall objective of the gender budgeting project is increased economic efficiency and effectiveness in budget allocations that take into account different needs of both genders. An objective is to ensure that gender equality objectives are reflected in budget policies and allocations at national and oblast levels. An additional objective is to encourage civil society discussion of gender equality principles in the context of the budget and to facilitate media engagement with such discussions.

The Ministry of Finance is leading on the initiative and is keen to knit together gender budgeting methodologies with budget reform methodologies. This approach of synchronizing the goals of results-oriented gender budgeting with sector-based results-based budgeting has become a guiding principle of many gender budget initiatives. To a large degree it owes its popularity to Austria, which introduced gender budgeting in tandem with reform of its budget. Another influence is a 2003 UN Women publication, written by Australian gender budget expert, Rhonda Sharp, which demonstrates the fit between performance-oriented budgeting and gender budgeting (Sharp, 2003). 
The gender budgeting initiative is oriented towards the attainment of the government's gender equality objectives as articulated in the State Program to Ensure Equal Status of Men and Women in Ukraine, 2013-2016. This Program is underpinned by the 2006 Law on Ensuring Equal Rights and Opportunities for Women and Men, which saw the establishment of a relatively active and, if only for a time, effective gender machinery. A current challenge to the promotion of gender equality, and one the gender budgeting project is cognizant of, is the deterioration of the gender machinery. Gender working groups, which were once active, no longer exist, and the Inter-Agency Council meets irregularly. The line ministries selected as primary beneficiaries were chosen in part because of their relevance to the attainment of gender equality: The Ministries for Social Policy, Youth and Sports, Economic Development and Trade, Health, and Education.

A particularly strategic dimension of the project is the collaboration between the newly established project team, the Friedrich Ebert Foundation and UN Women. This partnership of expertise, with its historic understanding and experience of the specificities of how the policy channels work in Ukraine is invaluable. Likewise, years of work in gender and development enable the project to identify gender inequality, and to bring this expertise to the relevant budget personnel.

\section{Observations/Conclusions on Case Studies}

Most gender budget initiatives have focused on the expenditure side of the budget and mostly in the social sectors. These are the areas where the relevance to gender is most evident to policy makers. The case of Andalucía is an example of a progressive rollout of the methodologies to include ultimately all budgetary measures. Framed as they are within the context of gender mainstreaming, all initiatives have the potential to do likewise.

As exceptions to the general trend, some countries have commissioned studies on the gender impact of revenue policy. Sweden and Austria have carried out such studies for a number of years, and lately, others, such as Finland, Spain and Ireland, have looked at the impact of taxation and welfare changes.

Coordination between gender equality goals and gender budgeting could be greatly improved. In most instances, where a gender equality strategy is in place, some of the goals articulated have overlap with national economic goals. Aligning gender budgeting initiatives with gender equality goals could provide the basis for better gender equality outcomes. Sweden and Finland are good examples where this coordination is in place and in the case of Ukraine, the goal is to work towards this.

Gender mainstreaming is a hugely ambitious project, for which resources have not always been adequate. The project of layering gender budgeting onto a gender mainstreaming framework that was already weak, has proved challenging. 
Understanding gender - how it is manifest in society and across the policy sectors, how and what data are required, how it can be applied as a category of analysis - is vital, if meaningful gender equality objectives are to be elaborated within the budgetary process. There is evidence that administrators are not seeking out, or not making sufficient use of gender expertise.

Decentralization has played a role in fueling a number of gender budget initiatives, and many experts believe that it is at the subnational level of government where gender budgeting can be most effective. This is particularly the case where significant spending authority is devolved to the lower levels, as in Belgium and Germany. Indeed, the high degree of devolved spending authority to the Lander level is one of the reasons why Germany has not pursued gender budgeting at the central government level.

Budgetary management and/or governance reforms have provided the stimulus and the framework for the introduction of gender budgeting in a number of countries. This has proven useful and is potentially a productive modality to further explore and exploit. However, there is some experience (Austria) that the gender dimension of budgetary reform is given less weight than other aspects of the reform package.

Gender budgeting, as currently practiced, is not getting at some of the macro-level budgetary decisions, which have the potential to have an important impact on women. This is particularly important in times of economic contraction, when decisions around cuts to public expenditure and on revenue policy are being made. Research clearly demonstrates that gender equality has suffered during this current period of austerity in many European countries and that commitments to gender budgeting have been challenged. ${ }^{17}$

Despite the emphasis on the participation of women - within the framework of gender mainstreaming as well as within the framework of development - in many instances little or no space is made for women's representation in the government-led processes of gender budgeting, despite that their analysis stands out and women's groups power many initiatives (as we will discuss), but no place has been created for them within the administration itself, where the institutions have been put in place.

Gender budgeting has played an important role in the development of gender equality policy in many countries, particularly those in the former Soviet sphere and Eastern Europe. In most instances this has been driven by the requirements of development agencies and other donor organizations. But it has also led to the activation of civil society there.

${ }^{17}$ See Karamessini and Rubery (2014). 
This survey has brought the focus onto civil society groups in Western Europe. This is also a feature in many of the states of Eastern and South Eastern Europe-such as Kosovo, FYR Macedonia, and Bosnia and Herzegovina, as a way to engage with emerging democratic institutions.

\section{Gender Budgeting and Revenue Policy}

\section{Introduction}

The tax code is an inherently complex instrument, reflective of a country's history, legal tradition, political structure, and economic base (Grown, 2010). It is an instrument that does not yield easily to change of any sort, let alone changes to accommodate gender equality. Taxes are generally considered in terms of their distributional effects and their effect on behaviors. In relation to distributional considerations, tax systems are analyzed in terms of vertical and horizontal equity or ability to pay. In relation to efficiency or incentive effects, taxes are analyzed in terms of how they affect behaviors, including labor supply, saving and investing, and risk-taking.

One can also look at incidence and incentive effects from a gender-differentiated perspective. Personal income taxes, including social security contributions, are generally the focus of these studies. From a distributional viewpoint, a number of studies have examined whether personal income taxes fall more heavily on women or men, reflecting their different position in the income distribution, labor supply, or wages. For taxpayers with equivalent incomes, some studies have examined the distributional effect disaggregated by sex, to capture the differential ability of women and men to make use of deductions and other tax preferences. From an efficiency viewpoint, many studies examine the differences in women and men's responses to income taxes, given their different behavior in economic markets. Much of the focus has been on how women and men's labor supply responds to changes in net wages and fiscal-policy induced changes in the effective cost of unpaid labor (De Henau, et al., 2010). ${ }^{18}$

The section begins with background discussion on reforms of tax systems during the latter part of the $20^{\text {th }}$ century that contributed to gender equality. Following this, we will look at Austria where, within the framework of an institutionally robust gender budget program, the Ministry of Finance has specified a tax-related gender equality objective. The discussion will then open up to look at a trend emerging in Western Europe where countries are acknowledging the importance of extending their gender budgeting activities to the realm of taxation.

\footnotetext{
${ }^{18}$ See also Meghir and Phillips (2009) for an extensive overview.
} 


\section{Background}

Stotsky (1996) is both a discussion of how gender bias can be found in tax systemsexplicitly and implicitly - particularly in relation to the personal income tax, and also a survey of reform in a number of countries, both developed and developing. Most countries in Europe reformed their tax codes to eliminate explicit gender bias in the 1970s and 1980s. Reform measures during this period saw the wife being granted the right to sign the tax forms (as in France and the United Kingdom); and the husband losing entitlement, under the tax law, to his wife's non-labor income (e.g., the United Kingdom). These reforms reversed the long-standing concept of "coverture" ${ }^{19}$ and thus removed a significant obstacle to a woman's standing as a legal entity in her own right and to her economic independence.

For some of the countries, this reform also entailed shifting from joint taxation to individual taxation, that is to say, from a system that treats the family as the unit of taxation to one where the individual is the unit. Under joint taxation, there typically would be no explicit bias against women because the household is taxed jointly. However, there was typically implicit bias against the secondary earner (predominantly women) because she would be faced with a higher marginal tax rate under progressive marginal tax rate schedules, which acts as a disincentive to work. Some European countries, including Germany, France and Portugal, still use a form of joint taxation, which has attracted some continuing comment and criticism. It has been observed, for example, that in Germany the system of "income splitting" for the purpose of joint filing, privileges couples with higher incomes and large intrahousehold income differentials. It thus reinforces the male breadwinner model and impedes gender equality through women's economic independence (Betzelt and Bothfeld, 2010; Palier and Thelen, 2010).

When it comes to sales-type taxes (e.g., value-added tax (VAT) and excises), there is no explicit gender bias because taxation applies to the sale of a good or service. However, there may be bias that is more implicit in nature. There are important design issues with a bearing on gender (Grown and Valodia, 2010). For instance, applying reduced VAT rates (either through zero-rating or exemption or lower than standard rates) on products used in the provision of care would help women, and in particular, women-headed households. High VAT rates as well as consumption taxes in general may also dampen labor supply as they reduce real wages (OECD, 2011). VAT also may distort the decision between buying goods and services on the market and producing them in the household (while the latter may dampen labor supply, particularly of women).

\footnotetext{
${ }^{19}$ The doctrine of coverture or "civil death" suspended women's legal capacities during marriage and prevented them from acquiring direct interests in property (Lahey, 2011, p. 17).
} 
From a macroeconomic perspective, decisions to increase the tax take, particularly in times of fiscal constraint, can contribute to the provision of much needed social programs that will enable women to better balance paid and unpaid work as well as mitigating the risk of a rise in poverty.

Tax reforms in the emerging markets of the former Soviet Union and Eastern Europe over the last decade have focused on transparency and efficiency, especially with regard to tax evasion and employment incentives. Motivated in large measure by the EU's call for tax harmonization, the emphasis has been on redistributing the tax burden to achieve a more equitable balance between personal and labor income taxes on the one hand, and consumption and environmental taxes on the other hand. Because the reform process was more focused on equity, in terms of ability to pay, gender considerations did not feature in the debate (Rastrigina and Verashchagina, 2015).

Leaving aside the removal of gender bias in the income tax code, there remains the issue of allowances and benefits. Some European governments, in an attempt to redistribute income between households, may introduce biases in favor of the traditional division of labor by assessing benefits on joint assessment of the household's income.

A number of studies show that, before childcare expenses, work pays even for the average secondary earner (Rastrigina and Verashchagina, 2015; OECD, 2012). Average effective tax rates evaluated at mean earnings for the woman are below 50 percent in all 26 EU-SILC ${ }^{20}$ countries, and below 30 percent in 15 of them. In addition, the median value of the marginal effective tax rate (METR) evaluated between zero and average earnings is below 50 percent in 23 of 26 countries and below 30 percent in 14 (Bettio andVerashchagina, 2009).

Fiscal stimuli designed to encourage women's employment have not been used extensively in Europe in recent decades. Bettio and Verashchagina (2009) show that in eight European countries with middle-to-low employment rates for women, the tax burden for secondary earners and lone mothers (those most at risk of labor market exclusion) diminished only marginally over the period 2001-2008.

The OECD (2012), in a study covering 30 countries over the period 1980-2007, confirmed that higher tax rates on secondary earners reduce women's labor force participation. The European Commission (EC, 2013, p. 45) recently reiterated that secondary earners often face specific disincentives to returning to work from inactivity or to increasing their work hours.

\footnotetext{
${ }^{20}$ EU-SILC is an annual, EU-wide survey on income and living conditions. It provides cross-sectional and longitudinal microdata on income, poverty, social exclusion and living conditions. National level data is gathered by national statistics offices and collated on a EU basis by Eurostat.
} 
Empirical studies find that labor supply elasticity is higher for low-income earners, in particular women with children (Meghir and Phillips, 2009). A higher tax-burden on secondary workers may therefore have a disproportionate negative effect on their employment outcomes.

\section{Gender budgeting and tax policy}

In recent years a trend appears to be developing to incorporate a focus on revenue policy in government gender budget initiatives. Austria has identified a gender equality objective, and a number of governments - including Spain, Finland, and Ireland - have committed to undertake studies looking at the gender aspects of revenue policy. This section will now focus on these new developments in gender budgeting.

\section{Austria}

Austria was earlier than most European countries to move to a system of individual taxation in 1972. Making the individual the unit of taxation, instead of the family, broadens the concept of horizontal equity and has been recognized as an important step towards women's economic independence, whether governments are motivated by gender equality or not. In the case of Austria, consideration was given at the time of the 1972 reform to the adoption of a "splitting" system, such as that in place in a small number of European countries, including Germany, Luxemburg, and Portugal. However, this was deemed inappropriate, mainly because of the disproportionate benefit to higher income earners, with little or no gain to lowincome earners. In addition, the higher tax rates required to support a splitting system would disadvantage single people.

In assessing the reform's impact on women's labor market participation, Dr. Edeltraud Lachmayer, an official and member of the Gender Mainstreaming Group in the Austrian Ministry of Finance, concludes that the lack of childcare provision and the prevailing traditional view of women's role in the home mitigated against the incentive toward encouraging women to increase their paid work, provided for by the reform. Further she suggests that, had the government of the day introduced the reform as an explicit gender equality reform - that is to say to support women's paid employment and independence- the resulting signal to society may have had the effect of expediting positive change for women. As it was, it took over a decade until substantial changes in women's labor market participation were noticeable.

Even before its engagement with gender budgeting, the Ministry of Finance had undertaken a regular study to examine the effectiveness of tax incentives, allowances and other aspects of the tax regime for men and women. Entitled "Is the Austrian tax system gender neutral?", the study was first undertaken in 2002 and updated in 2006, 2010, and 2016. According to one report, the first study revealed a male bias, in that a reduction of taxes for those with high 
incomes privileges men, who make up 90 percent of the high-income group. One response from the Ministry was to elaborate a set of controlling procedures for tax reform as well as for the national budget that would help avoid unintentional gender bias. Recent reports from the Ministry of Finance indicate that these procedures were deemed to be too time consuming and were not used for any length of time.

According to Lachmayer, a drawback of most of the studies conducted in Austria is that they only focus on the distributional side of taxation, and not on the behavioral impacts. With this in mind, the Gender Mainstreaming Group within the Ministry of Finance determined, as part of its legal obligation to gender budgeting, to suggest a gender equality objective that would potentially impact on behavior. Particularly concerned with the thorny issue of women's undue burden when it comes to unpaid care work, the Gender Mainstreaming Group was of the mind that, notwithstanding the impact of other gender sensitive reforms, unless there is a more equal distribution of paid and unpaid work between men and women, then gender equality will not be fully realized. Most observers are in agreement with this position (see, for example, Pearson and Elson, 2015; Rubery, 2015; Barry and Conroy, 2014). In addition to the potential to bring substantive change, such a policy also has the potential to change attitudes towards the roles of men and women in society at large, which ultimately will influence other relevant legislative and policy reform.

As noted elsewhere in this paper, every Ministry in Austria is required to formulate a gender equality objective for its budget. For the Ministry of Finance, that objective is that the tax system supports a better distribution of paid and unpaid work between women and men. Clearly this is not an objective that can be achieved in one budget cycle, or through the activation of any single measure. Thus, the objective will remain in place for some time to come, with successive budget cycles introducing new measures and refining existing ones toward a progressive realization of the objective.

Among the measures that will contribute to the gender objective is a reduced entry-level tax rate of 25 percent (previously 36.5 percent). As of 2016, a flatter progression will apply with the existing tax free earning level of EUR 11,000 remaining as it is; the entry rate of 25 percent applying to EUR 18,000, and rates rising thereafter through five levels to the highest marginal tax rate of 55 percent applying to earnings over EUR 1 million. Given that a substantial portion of those in employment who earn less than the tax-free basic personal allowance (Steuerfreibetrag) of EUR 11,000 are employed on a part-time basis (70 percent), a greater incentive than before is created to top up their part-time working hours to a level that is closer to full-time work or, indeed, to a full-time job. Accordingly, this measure supports part of the equality objective of achieving a better distribution of paid work between men and women. This will also lead to a reduction in the gender pay gap.

A reduction of standard tax rates results in relief of 1.3 percent for the highest incomes and up to 3.26 percent for low and middle incomes that exceed the tax threshold. Once the social 
security contribution refund (the so-called negative tax) is taken into account, incomes that are just over the lower earnings limit (Geringfügigkeitsgrenze) will benefit from the highest relief of 4.22 percent. As higher incomes receive relatively less relief, given the current income differential, the gap between the net disposable incomes of men and women will decline. ${ }^{21}$

Increases in tax allowances for children

Most of the benefits for children in Austria come in the form of cash transfers. However, there are two tax allowances for children. One is the sole earner benefit and as such is the one remaining element of household taxation. Applicable also to single parents, the allowance amounts to EUR 494 per year (which is very small relative to income per capita), with a supplement for more than one child. The partner of the sole earner must earn no more than EUR 6,000 per year.

The other tax allowance for children was introduced in 2009 and has, according to the Gender Mainstreaming Group, the potential to advance gender equality. Currently the allowance amounts to EUR 220 per child, per year; if both parents claim it, it amounts to EUR 132 per parent per child. From 2016, the child allowance will increase to EUR 440 per year, per child. As part of this reform, the benefit is enhanced when claimed by both partners. This means that, irrespective of their individual tax rate, each will be eligible to claim EUR 300 per child; should only one parent claim, the amount due will be EUR 440.

\section{Government-commissioned gender and revenue studies}

\section{Spain}

In its Equal Opportunities Strategic Plan, 2014-2016 (Government of Spain, 2014), the Spanish government committed to the analysis of the impact of taxation and public benefits so as to gauge the influence on women's labor market participation and their "professional prospects." The study would also look at how social security regulations affect men and women differently, and particularly the impact of those regulations related to part-time work. Three ministries are identified as being responsible for the study: The Ministries of Employment and Social Security, Public Administration, and Health, Social Services and Equality. It is worth noting that the study is planned as part of the broader objective of making progress in equality between women and men in the workplace and the fight against pay discrimination.

\footnotetext{
${ }^{21}$ For an overview of the measures of the tax reform and a simulation of their distributional effects, including from a gender perspective, see Schratzenstaller (2015) and Rocha-Akis (2015).
} 


\section{Finland}

Published in late 2015, the Finnish government's study on the differential impact of tax changes covered the period 1993 to 2012 (Riihela and Viitamaki, 2015). The study was motivated by the recognition that tax policy decisions may have an impact on economic equality between men and women and that analyses were necessary both to underpin policymaking and to develop a research base in this area. Focused primarily on changes in income and consumption taxes, the study also took account of changes in income levels, income distribution, and demography. The study reports that the taxation of earned income had decreased by some 8.5 percentage points, with women and men faring more or less equally. Changes included an increase on taxation on capital income, which had more impact on those with high incomes, a higher share of whom were men. While the study shows that changes in the tax rules resulted in little or no change for low-income people, this could be read to say that this income group has a disproportionately low share in the overall benefit of a lower tax regime. Finally, in relation to income tax, the study reports that a decrease of some sevenpercentage points in the combined tax on earned and capital income benefited women slightly more than men.

With respect to consumption taxes, the study pointed to the challenges of assessing the gender equality impact due to the inability of allocating the taxes to individuals. The many changes - up and down - in VAT cancelled each other out and the ratios of taxes on consumption stay almost unchanged during the period under scrutiny. The executive summary of the study also points to a change in the structure of consumption and the propensity to consume. The share of tax-free consumption has increased and the share of food and goods with a standard VAT has decreased. The question remains if the body of the report gives details on which goods these are and whether any gender implications can be inferred.

\section{Ireland}

Carried out by the Economic, Social and Research Institute, a study investigated the gender impact of tax and benefit policy changes over the period 2009 to 2013 (Keane et al., 2014). This was a period of successive austerity budgets in Ireland. Using a micro simulation model based on a large-scale nationally representative sample, the analysis sought to isolate the impact of changes in income tax, welfare benefits, property tax, and public sector pay. The study identified the impact of policy changes as distinct from changes in employment, unemployment or pre-tax incomes. Changes in disposable income were measured against a base of 2008, and compared to those in 2013.

The research found no sizeable gender difference of the impact of budgets from 2009-2013 for singles, with a loss of between 9 and 10 per cent for both men and women. For both single men and women without children, losses were greater at the bottom income quintile, 
driven by social welfare reductions; and at the top quintile, where losses related to taxation and public sector pay changes.

Two scenarios were investigated in relation to couples: one assuming full income sharing and the other assuming no income sharing. Using the assumption of full income sharing, couples of working age with no children experienced a reduction of just under 12 per cent, while couples with children and both partners working full time experienced the greatest losses at 13 per cent. Under the no income sharing assumption, women in working-age couples lost out more when it came to individual income: 15 per cent loss for women, compared to 10 per cent loss for men. Most of the gap was due to changes in child benefit and to social welfare reductions. Looking at the impact across the income distribution and assuming full income sharing, the findings show that tax and benefit changes in the 2009-2013 budgets were progressive. However, looking at individual incomes within couples, women lost a larger proportion of their income than men, right across the income distribution, with women in the poorest income quintile losing most.

Two of the main limitations of the research are that it does not take account of i) the differential impact of cuts in public services, nor ii) the impact of changes in indirect taxation. Work is ongoing to rework the model to accommodate these dimensions. The study acknowledges that neither scenario of full income sharing and no income sharing is likely to be accurate, but argues that the approach can help to put approximate bounds on the impact of policy. Finally, the study points to the usefulness of this approach to gender budgeting in that the method could be applied ex-ante and would allow a gender impact assessment to be built into the budgetary process.

\section{Gender Budgeting and Civil Society}

\section{Introduction}

Civil society has been a key driver of gender budgeting in Europe. Quinn (2009) details the activities of a number of groups, whose work contributed to the emergence of governmentled gender budgeting initiatives at both national and regional levels. While civil society fulfills a number of both supportive and critical roles to government in relation to gender budgeting, it is perhaps its application of gender expertise to standard economic policy that is of particular importance. At its most basic, the resultant analysis is a straightforward extrapolation of, on the one hand, how men and women contribute to and are impacted by the economy; and on the other of the factors that inhibit or enhance the participation of both men and women towards the realization of the country's full economic potential. While the analysis put forward does challenge certain normative economic assumptions, it is evidencebased analysis, indeed constantly pushing for the use of a wider spectrum of data in economic policy making. And its objective is sustainable economic growth and prosperity, for all. 
The contribution these groups make is vital to the broader project of gender budgeting for at least three reasons: i) framed as gender mainstreaming, the reach of gender budgeting has been largely been restricted to public expenditure, thus leaving many facets of fiscal policy unexamined; ii) the depth and caliber of the analysis renders the relevance of gender to economic policy indisputable; iii) its dissemination among a broad community of academics, policy-makers, public representatives and citizens has elevated the debate and educated the debaters.

This section takes a brief look at three civil society organizations: the UK Women's Budget Group; the Swedish Women's Lobby; and Spain’s la Plataforma ¡Impacto de Género YA!

\section{United Kingdom's Women's Budget Group}

The United Kingdom's Women's Budget Group is undoubtedly the best-known civil society organization active in promoting a gender equality perspective to all fiscal and budgetary policies. Indeed, it has become a model of how to apply gender sensitive analysis to fiscal policy, not just for civil society and academia, but also for governments. Many of its members are engaged by intergovernmental and funding agencies, as well as national governments, to provide analysis and expertise, develop tools and help with the development of appropriate methodologies for the implementation of gender budgeting in a broad range of settings. Made up of academics and activists, leaders and representatives of equality-focused non-governmental organizations, trade unionists, and students, the United Kingdom's Women's Budget Group encompasses a considerable fount of economic and policy expertise. Its work at home has as its fundamental concern the well-being of women and children, particularly those living in - or at risk of poverty. The vision is of a "gender equal society in which women's financial independence gives them greater autonomy at work, home, and in civil society." 22

Formed in the late 1980s during the Thatcher government, the group's initial project was to use allies within the government opposition to put forward parliamentary questions relating to the impact on women and children of existing or impending government policy. When the Blair government came into power, HM Treasury Department had a Memorandum of Agreement with the Women's Budget Group and, for a period of time, sought the group's analysis and advice on relevant policy matters. In response to an OECD questionnaire on Gender Mainstreaming, Competitiveness and Growth, October 2000, HM Treasury described the Women's Budget Group as a "key feature of the consultation process with respect to gender." During this time, the Women's Budget Group provided guidance to a gender budgeting pilot project involving three government ministries. The analysis of expenditure brought a focus on the government's New Deal Program and was important for raising

${ }^{22}$ Available at http://wbg.org.uk/about-us/ - last accessed January 7, 2016 
awareness and building capacity within government on the relevance of gender to the design of such programs. The project's findings, which informed the 2004 Spending Review, are documented in a HM Treasury 2004 report, "Gender Analysis of Expenditure Project." ${ }^{23}$

The Women's Budget Group's model of analysis is fundamentally a collaborative one and has evolved over the years to encompass a broad-based analysis of government economic policy, highlighting both the social as well as the gender equality implications. The gathering of group members to view live the Chancellor's budget statements has become an institution, allowing for a press release based on an initial analysis of the budget headlines. This is followed by a more in-depth and robust analysis, disseminated widely through its network of members, press, members of parliament etc.

In one of its earliest analysis in 2000, the Women's Budget Group organized its response to the government's pre-budget statement around three themes: i) delivering growth and macroeconomic stability; ii) promoting individual economic security; and iii) increasing national levels of employment and productivity. Within this frame, the analysis stressed that strategies for growth needed to take account of potential human costs so as to be equitable and sustainable; that the proposed modernization of the tax and benefit system and the ambitious New Deals Program be based on the individual, rather than the household, as the unit of economic policy analysis; and that the target of full employment needed to take account of education and training for women returning to employment, an adequately resourced National Childcare Strategy and an inclusive program of active labor market polices to include women not in employment.

The 2010 summer election brought a change of government. The new coalition government brought in a budget with a number of austerity measures to address the effects of the recession. A key theme of the Women's Budget Group's assessment of this budget was the obligation on government to carry out a gender impact assessment of the budget. This obligation - known as the gender equality duty - came out of legislation brought in by the previous government. The objective of a gender impact analysis is to signal the potential differential impact of a policy or law on men and women, thus allowing for an opportunity to mitigate any potential adverse impact while maximizing a positive outcome for gender equality.

While acknowledging the budget contained some measures - such as the exemption of low income workers from the public sector pay freeze - that would help to offset gender inequality, on the whole the impact of the budget would likely see a fall in women's participation in the labor market and the loss of the talents of many women to the economy.

\footnotetext{
${ }^{23}$ Available at http://wbg.org.uk/pdfs/cms-gender-expenditure-of-analysis-report-GAP-report_July-2004.pdf
} 
The resultant loss of earnings would trigger increases in the cost of tax relief and/or meanstested tax credits and benefits, thus increasing the budget deficit.

A recent example of the Women's Budget Group's reach and influence relates to its analysis of the Chancellor's 2015 Autumn Statement, in which it used the Chancellor's theme of security to critique the government for its failure to invest in women's security. In the House of Commons a few weeks later, that theme was again echoed during a debate, which sought to put the Conservative Party's "record under the microscope" in relation to gender equality commitments. A number of Members of Parliament referred extensively to the Women's Budget Group's analysis to argue that "women of all ages and backgrounds face an insecure and worrying future," with recent tax and benefits changes hitting women three times harder than men, a gender pay gap of 19.2 percent, cuts to services and the social infrastructure and a weakening of women's employment rights and opportunities (Green, 2015-2016). ${ }^{24}$

\section{Swedish Women's Lobby}

Founded in 1997, the Swedish Women's Lobby is a politically and religiously independent umbrella organization of over 35 member organizations, whose mission is to strengthen women's position in society. The Swedish Women's Lobby is founded on a feminist platform and bases its activities on the UN Convention on the Elimination of All Forms of Discrimination Against Women (CEDAW) and the Beijing Platform for Action to promote women's full human rights. Its work is primarily aimed at decision-makers and those in power and is framed within the goal of mainstreaming a woman's perspective into all political social and economic policies and contexts. The Swedish branch of the European Women's Lobby, the Swedish Women's Lobby also participates as a nongovernmental organization representative in the Swedish Government Delegation to the UN Commission on the Status of Women.

The Lobby began its analysis of the national budget in 2007. It wanted to assess the government's recent promise to bring a gender equality perspective to the budget. It also wanted to initiate a discussion, with government and within society, on the differential impact of budget decisions on men and women. The analysis found that while the budget document demonstrated an awareness of gender related problems and articulated gender equality objectives, the use of sex-disaggregated statistics was inadequate and a gender aware impact analysis of economic policy proposals had not been employed. That early analysis was self-consciously aware of entering a new domain - that of economic policy - and of providing a new way of uncovering inequalities in a country noted internationally for its better-than-average rating on gender equality.

\footnotetext{
${ }^{24} \mathrm{http} / /$ www.publications.parliament.uk/pa/cm201516/cmhansrd/cm151209/debtext/1512090003.htm\#15120945000005.
} 
In its analysis of the 2016 budget, the Lobby welcomes the increased use of gender statistics and commends the government for its overt commitment to, and what it sees to be the "launching" of, the concept of gender budgeting in Sweden. In terms of gender equitable budgetary measures, the Lobby welcomes the cutting back of tax credits, the lowering of tax on pensions, the increase in childcare allowance and the addition of a reserved month of parental leave. It also notes a strengthening of the infrastructure to better manage gender equality and calls on the government to monitor carefully the long-term impact of tax cuts on both women and men.

\section{La Plataforma ;Impacto de Género YA!}

La Plataforma Impacto de Género Ya (Platform for Gender Impact Now), a grouping of feminist and women's collectives, issue-based associations, and regional forums, formed in 2007. Initially its purpose was to challenge the Spanish government's failure to publish a Gender Impact Assessment of the national budget. The legal obligation to produce a Gender Impact Assessment is most strongly articulated in the Gender Impact Assessment Law of 2003 and further mandated via the Equality Law of 2007.

In 2007, the La Plataforma, initiated a legal challenge against the government; the challenge was rejected at that time by the public prosecutor but has since been accepted as legally competent by the Audiencia Nacional. Since then, the Spanish government has produced an annual Gender Impact Assessment, to which La Plataforma has responded, as well as issuing its own assessment of budget proposals from a gender perspective.

Of particular concern to Plataforma in assessing Spain's 2016 Budget was the overall slow rate of job growth, with recovery in employment not proportional to the GDP. This is against the backdrop of a loss of almost 3 million jobs in Spain between 2008 and 2012 and an unemployment rate of 24.4 percent in March 2012. At the time of the preparation of Budget 2016, women made up about half of the unemployed. Also of concern in relation to employment is a planned 21.7 percent cut in the level of unemployment benefit. La Plataforma points to the gap between those unregistered unemployed who are not covered by unemployment insurance, which according to 2014 figures showed that 63.8 percent of unemployed men were covered, while 54.2 percent of unemployed women were covered.

La Plataforma's analysis of the 2016 Budget focuses on four main areas:

- employment - continued slow growth of jobs and cuts to unemployment protection

- downgrading of women's equality infrastructure and resources

- insufficient to protect and support women victims of domestic violence

- the suspension of the law that would have extended paternity leave. 
La Plataforma welcomes the government's Gender Impact Report incorporated into the Budget, calling it a "significant improvement." However, it is concerned that while the measures outlined indicate the promotion of gender equality, the failure to identify the required budgetary allocations means that it is impossible to gauge to what extent the measures will be implemented and therefore the scope and evolution of the gender equality policy over the years.

\section{Conclusion}

Gender budgeting has enjoyed sustained support across Europe for more than a decade and a half. A number of national and regional governments have legislated for gender budgeting (e.g., Austria, Belgium, and Andalucía); many have initiated changes to the institutions of the budget (e.g., Albania, Belgium, and Iceland); while others have recommitted to the fundamental concept of marrying equality policy with economic policy (e.g., Sweden, Finland, and Iceland). In addition, civil society has provided expert gender analysis and has led the way in broadening the debate on fiscal policy by demonstrating that gender budgeting contributes to good budgeting - budgeting that accounts for the social and economic benefits of women's equality and economic empowerment.

Government-led gender budget initiatives are most commonly implemented in the framework of gender mainstreaming. The traditionally held view of the budget as a gender-neutral instrument, and the resistance of Ministries of Finance to the uptake of gender mainstreaming, have given way to a broad and diverse tapestry of experimentation, adaptation and integration.

The practice of gender budgeting across Europe is almost exclusively associated with the expenditure side of the budget, and in particular with expenditure related to the delivery of public services. There are exceptions to this trend; in Austria, within the framework of an institutionally robust gender budget program, the Ministry of Finance has specified a taxrelated gender equality objective; and some countries have acknowledged the importance of extending their gender budgeting activities to the realm of taxation.

Today, the personal income taxes in most European countries are gender neutral and taxation is largely on an individual basis. Nevertheless, secondary earners, the majority of whom are women, often face disincentives to entering, or increasing their participation in, the labor market. In addition, while individual taxation is in place, the assessment of benefits by most governments is most often based on joint assessment of their income. Implicit gender bias still applies to sales-type taxes; applying reduced VAT rates on products used in the provision of care would help women, and in particular, women-headed households. 
Decisions on whether and how to increase the tax take can have a differential burden on men and women, as well as having an effect on social programs, which help women to balance paid and unpaid work.

This paper examines the status of gender budgeting in the context of the status of gender equality policy in Europe. The European Union has had, on aggregate, a positive influence on the development of gender equality policy, not only in the Member States, but also in the rest of Europe, with whom it has some formal relationship. Indications of a weakening of the EU social agenda do not bode well for gender equality policy, including innovations like gender budgeting.

Despite the prevalence of both debate and activity on gender budgeting, policy makers have not taken sufficient account of gender equality when it comes to the design of recent austerity measures. As a consequence, the combined effect of structural reforms and retrenchment to social protection systems, as well as changes in unemployment for women since 2011 and projections into the future, suggest that women are at heightened risk of poverty and there is thus all the more need for European countries to take gender into account in budgeting in the face of continued austerity.

Coordination between gender equality goals and gender budgeting could be greatly improved. Sweden and Finland are good examples where this coordination is in place and in the case of Ukraine, the goal is to work towards this. In addition, budget administrators are not seeking out, nor making sufficient use of gender expertise in fiscal policy-making.

Budgetary and/or governance reforms, including decentralization, have provided the stimulus and the framework for the introduction of gender budgeting in a number of countries. Many experts believe that it is at the regional and local levels of government where gender budgeting can be most effective.

Gender budgeting has played an important role in the development of gender equality policy in many countries, particularly the newly independent former-Soviet countries. Likewise, it has been instrumental in activating civil society. 
While many initiatives have not been in place long enough to evaluate concrete gender equality outcomes, it is clear from this survey that significant legislative, administrative and methodological changes have been undertaken in the institutions of the budget. Such changes, if maintained and acted upon provide the framework for the ongoing meaningful consideration of gender equality in the formulation and execution of the budget.

Where gender budgeting has been in place for a number of years (e.g. Austria, Belgium, Berlin, Andalucía) it behooves the governments of those jurisdictions to commission independent evaluations so that the lessons gained can be fed into ongoing work. 


\section{References}

Adam, Stuart, and James Browne, 2006, "Redistribution, Work Incentives and Thirty Years of UK Tax and Benefit Reform," IFS Working Paper 10/24 (London: Institute for Fiscal Studies).

Aguilera Diaz, Buenaventura, Alicia Del Olmo Garrudo, Ana Isabel Escobar Arroyo, 2011, "La Experiencia de Presupuestacion con Perspective de Genero en la Junta de Andalucia: Analisis de las Diferentes Fases del Proceso," Presupuesto y Gasto Publico, Vol. 64, pp. 59-80.

Austrian Federal Budget Reform e-learning, available online.

Barry, Ursula, 2014, "Gender Perspective on the Economic Crisis: Ireland in an EU Context," Gender, Sexuality \& Feminism. Vol. 1, pp. 82-103.

Barry, Ursula, and Pauline Conroy, 2014, "Ireland in Crisis-Gender, Inequality and Austerity," in Maria Karamessini and Jill Rubery, editors, Women and Austerity: The Economic Crisis and the Future for Gender Equality (Abingdon: Routledge).

Bettio, Francesca, and AlinaVerashchagina, 2009, Gender Segregation in the Labour Market: Root Causes, Implications, and Policy Responses in the EU (Luxembourg: $\mathrm{EU})$.

Betzelt, Sigrid, and Silke Bothfeld, 2011 "Incoherent Strategies-Fragmented Outcomes: Raising Women's Employment Rate in Germany," German Policy Studies, Vol. 7, pp. 73-106.

Bjorklund, Erika, 2007, "Issue Histories Sweden: Series of Timelines of Policy Debates, Quality in Gender and Equality Policies," (Vienna: Institute for Human Sciences).

Bretherton, Charlotte, 2001, "Gender Mainstreaming and EU Enlargement: Swimming against the Tide?" Journal of European Public Policy, Vol. 8, pp. 60-81.

Crouch, Colin, 2015, "Can the European Union Abandon Social Policy?" UCD Society of Politics and International Relations Understanding the Eurozone Crisis Seminar Series, November.

Daly, Mary, 2011, "What Adult Worker Model: A Critical Look at Recent Social Policy Reform the Europe from a Gender and Family Perspective," Social Politics, Vol. 19, pp. 1-23. 
Daly, Mary, 2013, "Parenting Support: Another Gender Related Policy Illusion in Europe," Women's Studies International Forum, Vol. 41, pp. 223-30.

De Henau, Jerome, Susan Himmelweit, and Cristina Santos, 2010, "Gender Equality and Taxation: A UK Case Study," in Caren Grown and Imraan Valodia, editors, Taxation and Gender Equity: A Comparative Analysis of Direct and Indirect Taxes in Developing and Developed countries, (Abingdon, Routledge).

Einarsdóttir, Thorgerdur, 2010, "The Policy on Gender Equality in Iceland" Study for the European Parliament's Committee on Women's Rights and Gender Equality (FEMM), PE 425.633.

Elson, Diane, Radhika Balakrishnan, and James Heintz, 2013, "Public Finance, Maximum Available Resources and Human Rights," in Aoife Nolan, Rory O'Connell, and Colin Harvey, editors, Human Rights and Public Finance: Budgets and the Promotion of Economic and Social Rights (Oxford: Hart Publishing).

Elson, Diane, 2003, Gender Mainstreaming and Gender Budgeting, paper given at conference on Gender Equality and Europe's Future.

Elson, Diane, 2002, “Gender Responsive Budget Initiatives: Some Key Dimensions and Practical Examples," paper presented at the conference on Gender Budgeting Financial Markets, Financing for Development (Berlin: Heinrich Boell Foundation), pp. 19-20.

Elson, Diane, 1998, The Gender Budget Initiatives: Background Papers (London: Commonwealth Secretariat).

European Union Advisory Committee on Equal Opportunities for Women and Men, 2003, Opinion on gender budgeting.

European Commission, 2013, Tax Reforms in EU Member States, Taxation Papers series, Working Paper N. 38.

Färber, Christine, Renee Parlar, Manfred Kohnen, Birgitt Cleuvers, 2006, Feasibility Study on Gender Budgeting at the Federal Level (Berlin: Federal Ministry for Family, Seniors, Women, and Youth).

Frey, Regina, and Manfred Kohnen, 2012, Guidance on Gender Budgeting in Public Administration, (Vienna: Federal Chancellery). 
Fritz, Elfriede, 2011, "Gender Budgeting: From Theory to Practice: The Role of the Ministry of Finance," paper given at the Council of Europe Conference in Yerevan.

German Federal Ministry of Finance, Federal Law Gazette BGBl II Nr. 289/2009.

Green, Kate, M.P., 2015-2016, Women and the Economy, House of Commons Debates, Vol. 603, Columns 1053-1057.

Grown, Caren, 2010, "Taxation and Gender Equality: A Conceptual Framework" in Caren Grown and Imraan Valodia, editors, Taxation and Gender Equity: A Comparative Analysis of Direct and Indirect Taxes in Developing and Developed Countries, (Abingdon, Routledge).

Gualda Romero, Maria Jose, Buenaventura Aguilera Diaz, and Paula Cirujano Campano, 2015, "Progress in the Andalusian GRB Practice: Gender Budgeting Audits," Journal of Economic Policy, Vol. 31, pp. 253-71.

Hammerschmid, Gerhard, and Alexander Grunwald, 2014, Einführung der Wirkungsorientierten Verwaltungssteuerung: Erfolge-Potentiale-Perspektiven, (Introduction of Results-Based Management Control: Success, Potential, Perspectives) (Vienna: Federal Chancellery).

Henninger, Annette, Christine Wimbauer, and Rosine Dombrowski, 2008, "Demography as a Push Toward Gender Equality? Current Reforms of German Family Policy," Social Politics, Vol. 15, pp. 287-314.

Holvoet, Nathalie, 2006, Gender Budgeting: Its Usefulness in Programme-Based Approaches to Aid, (Brussels: European Community Gender Helpdesk).

Holvoet, Nathalie, 2007, "Gender Budgeting in Belgium: Findings from a Pilot Project," European Societies, Vol. 9, pp. 275-300.

Iceland, Government of, 2011, Implementing Gender Budgeting: Three Year Plan, Ministry of Finance.

Jones, Rowan, and Klaus Lüder, 2011, "The Federal Government of Germany's Circumspection Concerning Accrual Budgeting and Accounting," Public Money \& Management, Vol. 31, pp. 265-70.

Joly, Carine, 2009, "Gender Mainstreaming: A New Challenge for the Federal Government and the Administrations," speech, available at http://www.oecd.org/mena/governance/43087796.pdf. 
Karamessini, Maria, and Jill Rubery, 2014, "Economic Crisis and Austerity: Challenges to Gender Equality," in Women and Austerity: The Economic Crisis and the Future for Gender Equality, Maria Karamessini and Jill Rubery, editors (Abingdon: Routledge), pp. 314-51.

Keane, Claire, Tim Callen, and John R. Walsh, 2014, Gender Impact of Tax and Benefit Changes: A Microsimulation Approach (Dublin: Economic and Social Research Institute).

Lahey, Kathleen, 2011, "The 'Capture' of Women in Law and Fiscal Policy: The Tax/Benefit Unit, Gender Equality, and Feminist Ontologies," in Kim Brooks, Asa Gunnarsson, Lisa Philipps and Marie Wersig, editors, Challenging Gender Inequality in Tax Policy Making (Portland: Hart Publishing).

McCracken, Katie, Matteo Jessoul, Antigone Lyberak, Will Bartlett, and Ewa Kusidel, 2013, "Gender Aspects of the Effects of the Economic Downturn and Financial Crisis on Welfare Systems," European Parliament's Committee on Women's Rights and Gender Equality, PE 474.396.

Meghir, Costas, and David Phillips, 2009, “Labor Supply and Taxes,” Mirrlees Review, Institute for Fiscal Studies.

Ministry of Social Affairs and Health, Finland, 2012, Government Action Plan for Gender Equality, 2012-2015.

Network of legal experts in the field of gender equality (NLEGE), Report on EU Gender Equality Law, 2014, European Commission, Directorate-General for Justice, Unit $\mathrm{JUST} / \mathrm{D} / 1$, available online.

Nordic Council of Ministers, 2015, Together for Gender Equality-a Stronger Nordic Region: Nordic Co-operation Programme on Gender Equality, 2015-2018. http://www.norden.diva-portal.org/smash/get/diva2:786318/FULLTEXT01.pdf

Nordic Council of Ministers, 2006, Integration of a Gender Perspective in the Budgetary Process, Country Reports.

Numhauser-Henning, Ann, 2015, "The Policy on Gender Equality in Sweden," study for the European Parliament's Committee on Women's Rights and Gender Equality, PE 510.011 . 
O'Hagan, Angela, 2015, "Favourable Conditions for the Adoption and Implementation of Gender Budgeting: Insights from Comparative Analysis," Special Issue of Economic Policy/Politica Economica.

Onwen-Huma, H., 2012, Gender Budgeting in Finland, presentation given at a Council of Europe Meeting of Gender Focal Points on behalf of the Ministry of Social Affairs and Health. PPP accessed 20 September, 2015. http://www.coe.int/t/DGHL/STANDARDSETTING/EQUALITY/07genderbudgeting /Ohrid/HOH_Ohrid.pdf

Organization of Economic Cooperation and Development, 2012, Closing the Gender Gap: Act Now, OECD Publishing.

Organization of Economic Cooperation and Development, 2013, Employment Outlook 2013, OECD Publishing.

Palier, Bruno and Kathleen Thelen, 2010, "Institutionalizing Dualism: Complementarities and Change in France and Germany," Politics \& Society, Vol. 38, pp. 119-48.

Pascall, Gillian and Jane Lewis, 2004, "Emerging Gender Regimes and Policies for Gender Equality in a Wider Europe," Journal of Social Policy, Vol. 33, pp. 373-94.

Pavan-Woolfe, Louise, 2005, "Gender Budgeting in the European Union and in the EU Policies," paper given at a conference in Vienna.

Pearson, Ruth, 2014, "Gender, Globalization and the Reproduction of Labor: Bringing the State Back In," in New Frontiers in Feminist Political Economy, Shirin M. Rai and Georgina Waylen, editors (Abingdon: Routledge).

Pearson, Ruth and Diane Elson, 2015, "Transcending the Impact of the Financial Crisis in the United Kingdom: Toward Plan F-a Feminist Economic Strategy," Feminist Review, Vol. 109, pp. 8-30.

Quinn, Sheila, 2009, Gender Responsive Budgeting Practical Implementation Handbook, (Strasbourg: Council of Europe).

Quinn, Sheila, 2013, "Equality Proofing the Budget: Lessons from the Experiences of Gender Budgeting," in Aoife Nolan, Rory O'Connell, and Colin Harvey, editors, Human Rights and Public Finance: Budgets and the Promotion of Economic and Social Rights (Oxford: Hart Publishing). 
Quinn, Sheila, 2015, The National Budget - Unsuitable Domain: Understanding Germany's Rejection of Gender Budgeting, Masters Thesis, University College Dublin

Rastrigina, Olga, and Alina Verashchagina, 2015, Secondary Earners and Fiscal Policies in Europe (Luxembourg: EU).

Riihela, Marja and Heikki Viitamaki, 2015, Veromuutosten vaikutukset sukupuolen mukaan vuosina 1993-2012, Government Institute for Economic Research, Helsinki.

Rocha-Akis, Silvia, 2015, The Distributional Effects of the 2015-16 Tax Refrom, WIFO Bulletin, 2015, 20(21), pp. 238-249, Vienna.

Rubery, Jill, and Anthony Rafferty, 2014, "Gender, Recession and Austerity in the UK," in Maria Karamessini and Jill Rubery, editors, Women and Austerity: The Economic Crisis and the Future for Gender Equality (Abingdon: Routledge), pp. 123-43.

Rubery, Jill, 2015, “Austerity and the Future for Gender Equality in Europe," Industrial and Labor Relations Review, Vol. 68, pp. 715-41.

Schmitz, Catharina, 2006, "Now It's About the Money: Mainstreaming a Gender Equality Perspective into Nordic National Budgets. Final Project Report 2004-2006," Copenhagen, Nordic Council of Ministers.

Schratzenstaller, Margit, 2014, “Gender Impact Assessment,” Exchange of Good Practices on Gender Equality Discussion Paper, European Commission, Brussels. http://ec.europa.eu/justice/genderequality/files/exchange_of_good_practices_at/at_discussion_paper_at_2014_en.pdf

Schratzenstaller, Margit, 2015, “The Tax Reform 2015-16-Measures and Overall Assessment," WIFO Bulletin, 2015, 20(20), pp. 222-237, Vienna.

Sedelmeier, Ulrich, 2009, "Post-Accession Compliance with EU Gender Equality Legislation in Post-Communist New Member States," European Integration Online Papers (ELoP) No. 2, Vol. 13, Art. 23.

Senate, Department of Labor Integration, and Women (DLIW), 2016, Budget 2016/2017 (Berlin).

Sharp, Rhonda, 2003, Budgeting for Equity: Gender Budget Initiatives within a Framework of Performance Oriented Budgeting, (New York: United Nations Development Fund for Women). 
Sloat, Amanda, 2004, "Legislating for Equality: The Implementation of the EU Equality Acquis in Central and Eastern Europe," No 8, Jean Monnet Working Papers, Jean Monnet Chair, available online.

Spain, Government of, 2014, Equal Opportunities Strategic Plan, 2014-2016, Institute for Women and Equal Opportunities under the Ministry of Health, Social Services and Equality, Madrid.

Steger, Gerhard, 2010, “Gender Budgeting, the Austrian Experience," Ministry of Finance, Austria.

Stotsky, Janet, 1996, “Gender Bias in Tax Systems," International Monetary Fund Working Paper 96/99 (Washington, DC: IMF).

, Sakina Shibuya, Lisa Kolovich, and Suhaib Kebhaj, 2016, "Trends in Women's Advancement and Gender Equality," International Monetary Fund Working Paper 16/21 (Washington, DC: IMF).

Stotsky, Janet G., 2016, “Gender Budgeting: Fiscal Context and Overview of Current Outcomes," International Monetary Fund Working paper 16/149 (Washington, DC: IMF).

Sveriges Kvinnolobby, 2015, Kommenlevar Budget-Propositionen 2016, Available at http://sverigeskvinnolobby.se/wp-content/uploads/2015/09/Sveriges-Kvinnolobbykommenterar-budgeten.pdf

Sweden, Government Offices of, 2006, "Moving Ahead: Gender Budgeting in Sweden," Ministry of Integration and Gender Equality. http://www.retepariopportunita.it/Rete_Pari_Opportunita/UserFiles/news/moving ahead_gender budgeting_in sweden.pdf

Thorsdottir, Thora Kristin, 2014, "Iceland in Crisis : Gender Equality and Social Equity," in Maria Karamessini and Jill Rubery, editors, Women and Austerity: The Economic Crisis and the Future for Gender Equality (Abingdon: Routledge), pp. 102-22.

Troupin, Steve, Jess Stroobants, and Trui Steen, 2013, "The Impact of the Fiscal Crisis on Belgian Federal Government: Changes in the Budget Decision Making Process," paper given at a conference in Talinn, Estonia, May.

Valkama, Paivi, 2009, “Gender Budgeting in Finland,” Ministry of Finance, Finland. http://fjarmalaraduneyti.is/media/PPT-kynningar/Gender_Budgeting_in Finland.pdf. 
Women's Budget Group, 2012, "The Impact on Women of Autumn Financial Statement 2012 and Welfare Benefits Up-Rating Bill 2013," available at http://wbg.org.uk/pdfs/WBG-AFS-2012-FINAL-\%5B2\%5D\%281\%29.pdf.

Women's Consortium of Ukraine, 2014, National Review of Implementation of the Beijing Declaration and Platform for Action. Available at: http://www.unece.org/fileadmin/.../NV111.07_att1_att2_att3_merged.pdf. 


\section{Appendix A: Gender Budgeting in Europe Data Template}

\begin{tabular}{|c|c|c|c|c|c|c|c|c|c|c|}
\hline & \multicolumn{8}{|c|}{ National Initiatives } & \multicolumn{2}{|c|}{ Subnational Initiatives } \\
\hline & Albania & Austria & Belgium & Finland & Iceland & Macedonia, FYR & Sweden & Ukraine & Andalucia & Berlin \\
\hline \multicolumn{11}{|l|}{ ORIGINS } \\
\hline Does the government have a gender budgeting initiative & Yes & Yes & Yes & Yes & Yes & Yes & Yes & Yes & Yes & Yes \\
\hline If yes, start year & 2012 & 2004 & 2004 & 2006 & 2006 & 2012 & $2002 / 2014$ & 2003 & 2003 & 2002 \\
\hline \multicolumn{11}{|l|}{ If any, end year } \\
\hline Supported by international organizations or bilateral aid agencies & Yes & No & No & No & No & Yes & No & Yes & No & No \\
\hline Tied to MDGs or national development plan or gender equality strategy & Yes & No & Yes & No & Yes & Yes & No & Yes & Yes & No \\
\hline \multicolumn{11}{|l|}{ SELECTED COMPONENTS OF FISCAL POLICY } \\
\hline Focus on spending & Yes & Yes & Yes & Yes & Yes & Yes & Yes & Yes & Yes & Yes \\
\hline Spending focus on key human development (education and health) & Yes & No & Yes & Yes & Yes & Yes & Yes & Yes & Yes & Yes \\
\hline Spending focus on physical infrastructure (transport, water, electricity, and energy) & Yes & Yes & Yes & Yes & Yes & Yes & Yes & Yes & Yes & Yes \\
\hline Spending focus on justice and security (violence against women, judicial assistance) & Yes & Yes & Yes & Yes & Yes & Yes & Yes & Yes & Yes & Yes \\
\hline Spending focus on jobs, entrepreneurship, wages etc & Yes & Yes & Yes & Yes & Yes & Yes & Yes & Yes & Yes & Yes \\
\hline Structural reforms in spending (subsidies, transfers, incentive or distributional objectives) & Yes & Yes & No & Yes & Yes & Yes & Yes & No & No & No \\
\hline Focus on revenue & No & No & No & Yes & Yes & No & No & No & No & No \\
\hline Personal income tax focus & No & No & No & Yes & No & No & No & No & No & No \\
\hline Other tax focus, including general or selective sales and trade & No & No & No & Yes & No & No & No & No & No & No \\
\hline \multicolumn{11}{|l|}{ INDICATORS TO PLACE GENDER BUDGETING IN THE FISCAL PROCESS } \\
\hline Broad statement of goals of Minister of Finance & Yes & Yes & Yes & Yes & Yes & Yes & Yes & Yes & Yes & Yes \\
\hline Gender budgeting statement in budget documentation & Yes & Yes & Yes & Yes & Yes & Yes & Yes & No & Yes & Yes \\
\hline Gender budgeting circular or related to instruct the bureaucracy & Yes & Yes & Yes & Yes & Yes & Yes & Yes & No & Yes & Yes \\
\hline Gender budgeting in planning and programming & Yes & Yes & Yes & Yes & Yes & Yes & Yes & No & Yes & Yes \\
\hline Gender budgeting outcome report or audit & Yes & Yes & No & Yes & Yes & No & Yes & No & Yes & Yes \\
\hline Explicit reporting on gender equality spending & Yes & Yes & No & Yes & Yes & No & Yes & No & Yes & Yes \\
\hline \multicolumn{11}{|l|}{ LEGAL BASIS } \\
\hline Gender budgeting has constitutional standing & No & Yes & No & No & No & No & No & No & Yes & No \\
\hline Gender budgeting is incorporated in organic budget or other finance laws & No & Yes & No & No & Yes & No & No & No & Yes & No \\
\hline \multicolumn{11}{|l|}{ ROLE OF GOVERNMENT } \\
\hline Ministry of Finance lead entity & Yes & Yes & Yes & Yes & Yes & Yes & No & Yes & Yes & Yes \\
\hline Other ministries play consequential role and which & Yes & Yes & Yes & Yes & Yes & Yes & Yes & Yes & Yes & Yes \\
\hline Subnational government & No & Yes & No & No & Yes & Yes & Yes & Yes & No & No \\
\hline \multicolumn{11}{|l|}{ ROLE OF CIVIL SOCIETY } \\
\hline Significant encouragement or participation of civil society & No & Yes & No & Yes & Yes & Yes & Yes & Yes & No & Yes \\
\hline
\end{tabular}

